Published in final edited form as:

J Am Chem Soc. 2005 December 7; 127(48): 16812-16823.

\title{
QZ1 and QZ2: Rapid, Reversible Quinoline-Derivatized Fluoresceins for Sensing Biological Zn(II)
}

\author{
Elizabeth M. Nolan $\dagger$, Jacek Jaworski $\ddagger, \|, \perp$, Ken-Ichi Okamoto $\ddagger, \|, \S$, Yasunori Hayashi $\ddagger, \|, \S$, \\ Morgan Sheng $\ddagger, \|, \S, \perp$, and Stephen J. Lippard ${ }^{\dagger}$ \\ $\dagger$ Department of Chemistry, Massachusetts Institute of Technology, Cambridge, Massachusetts \\ 02139
}

|| Department of Brain and Cognitive Sciences, Massachusetts Institute of Technology, Cambridge, Massachusetts 02139

$\ddagger$ Picower Institute for Learning and Memory, Massachusetts Institute of Technology, Cambridge, Massachusetts 02139

$\S$ RIKEN-MIT Neuroscience Research Center, Massachusetts Institute of Technology, Cambridge, Massachusetts 02139

$\perp$ Howard Hughes Medical Institute, Massachusetts Institute of Technology, Cambridge, Massachusetts 02139

\section{Abstract}

QZ1, 2-[2-chloro-6-hydroxy-3-oxo-5-(quinolin-8-ylaminomethyl)-3H-xanthen-9-yl]benzoic acid, and QZ2, 2-[6-hydroxy-3-oxo-4,5-bis-(quinolin-8-ylaminomethyl)-3H-xanthen-9-yl]benzoic acid, two fluorescein-based dyes derivatized with 8-aminoquinoline, have been prepared and their photophysical, thermodynamic, and zinc-binding kinetic properties determined. Because of their low background fluorescence and highly emissive Zn(II) complexes, QZ1 and QZ2 have a large dynamic range, with 42- and 150-fold fluorescence enhancements upon $\mathrm{Zn}$ (II) coordination, respectively. These dyes have micromolar $K_{\mathrm{d}}$ values for $\mathrm{Zn}$ (II) and are selective for $\mathrm{Zn}$ (II) over biologically relevant concentrations of the alkali and alkaline earth metals. The $\mathrm{Zn}$ (II) complexes also fluoresce brightly in the presence of excess $\mathrm{Mn}(\mathrm{II}), \mathrm{Fe}(\mathrm{II}), \mathrm{Co}(\mathrm{II}), \mathrm{Cd}(\mathrm{II})$, and $\mathrm{Hg}(\mathrm{II})$, offering improved specificity for Zn(II) over di(2-picolyl)amine-based Zn(II) sensors. Stopped-flow kinetic investigations indicate that QZ1 and QZ2 bind $\mathrm{Zn}$ (II) with $\mathrm{k}_{\text {on }}$ values of $(3-4) \times 10^{6} \mathrm{M}^{-1} \mathrm{~s}^{-1}$, compared to $(6-8) \times 10^{5} \mathrm{M}^{-1} \mathrm{~s}^{-1}$ for select $\mathrm{ZP}$ (Zinpyr) dyes, at $4.3^{\circ} \mathrm{C}$. Dissociation of $\mathrm{Zn}$ (II) from QZ1 and QZ2 occurs with $k_{\text {off }}$ values of 150 and $160 \mathrm{~s}^{-1}$, over 5 orders of magnitude larger than those for ZP probes, achieving reversibility on the biological (millisecond) time scale. Laser scanning confocal and two-photon microscopy studies reveal that QZ2 is cell-permeable and Zn(II)-responsive in vivo. Because of its weaker affinity for Zn(II), QZ2 responds to higher concentrations of intracellular Zn (II) than members of the ZP family, illustrating that binding affinity is an important parameter for $\mathrm{Zn}$ (II) detection in vivo.

Correspondence to: Stephen J. Lippard.

E-mail: lippard@mit.edu.

Supporting Information Available: Full listing of authors of ref ${ }^{14}$; Figures S1-S23, which include fluorescence titrations (S1); the reversibility of QZ binding to Zn(II) following TPEN addition (S2); a Job plot for Zn(II) binding to QZ1 (S3); metal ion selectivity plots for QZ1 (S4); representative kinetic traces and plots of $k_{\mathrm{obs}}$ versus initial [dye] (S5-S9); plots of $k_{\mathrm{obs}}$ versus [Zn(II)] (S10-S14); Eyring plots (S15-S19); relative fluorescence emission of the Zn(II)-bound sensors (S20); and both confocal and two-photon microscopy images of biological samples (S21-S23); and experimental details for the representative kinetic analyses. This material is available free of charge via the Internet at http://pubs.acs.org. 


\section{Introduction}

Zinc is an essential structural or catalytic component in over 300 metalloproteins, ${ }^{1}$ is required for proper immune function, ${ }^{2}$ is involved in DNA repair, ${ }^{3}$ regulates caspase activity and apoptosis, ${ }^{4}$ and is a proposed modulator of neurotransmission. ${ }^{5}$ Although most zinc is tightly bound to proteins and its concentrations are strictly regulated by specific zinc transporters 6 and metallothionein, ${ }^{7}$ pools of loosely bound and histochemically observable zinc exist in several tissues, including the pancreas ${ }^{8}$ and brain. ${ }^{5 a, c}$ In the synaptic clefts of the mossy fiber region of the hippocampus, a region of the brain associated with learning and memory, concentrations of $\mathrm{Zn}(\mathrm{II})$ are reported to reach micromolar to submillimolar levels under normal physiological conditions. 9 This "free" zinc is housed in synaptic vesicles, presumably colocalized with glutamate, but its functional significance remains a mystery. 9,10 Pathologically, disruptions in zinc homeostasis have been associated with susceptibility to infectious diseases, 2 brain trauma and seizure, ${ }^{11}$ and disorders that include depression, ${ }^{12}$ diabetes, ${ }^{13}$ prostrate cancer, ${ }^{14}$ and several neurodegenerative states including Alzheimer's disease. ${ }^{15}$

To explore the trafficking of physiological and pathological zinc, much effort has been devoted to devising new tools and tactics for zinc detection. ${ }^{16}$ Fluorescence imaging in particular is well-suited for live imaging of biological Zn(II), which has no facile spectroscopic or magnetic signature. Successful application of this methodology requires the development of robust $\mathrm{Zn}$ (II) imaging agents with high sensitivity, selectivity, and temporal fidelity. A variety of fluorescence-based approaches to $\mathrm{Zn}$ (II) detection have been documented recently, including small-molecule intensity-based ${ }^{17}$ and ratiometric ${ }^{18}$ sensors, as well as methods based on proteins ${ }^{19}$ or peptides. ${ }^{20}$ Although many of these systems are well-suited for investigating biological samples, arguably all suffer from one or more limitations, which continues to inspire the search for improved Zn(II) imaging tools.

The most widely used fluorescent histological Zn(II) stains, TSQ ( $N$-(6-methoxy-8-quinolyl)$p$-toluenesulfonamide) and its congeners (Figure 1), are quinoline derivatives bearing sulfonamide groups that give substantial fluorescence enhancement upon $\mathrm{Zn}$ (II) coordination. 21 Zinquin E, which harbors an ester moiety that hydrolyzes in vivo, is commonly employed because of its improved solubility, membrane permeability, and intracellular retention. These dyes require high-energy UV excitation (TSQ, $\left.\lambda_{\mathrm{ex}}\right) 334 \mathrm{~nm}$; Zinquin, $\lambda_{\mathrm{ex}} 370 \mathrm{~nm}$ ), however, which is potentially damaging to biological tissues and can induce autofluorescence from endogenous components. Despite a large dynamic range, these probes exhibit relatively dim emission deriving from a weakly fluorescent reporting group $\left(\Phi_{\mathrm{Zn}} \approx 0.1\right)$. For biological imaging applications, fluorescein is a superior chromophore because of its high brightness $(\Phi$ $\times$ [epsilon1]; $\Phi \approx$, high [epsilon1]), water solubility, desirable excitation $(\sim 480-500 \mathrm{~nm})$ and emission $(\sim 520 \mathrm{~nm})$ wavelengths, and the availability of suitable microscope equipment. Fluorescent $\mathrm{Zn}$ (II) sensors with one or two appended di(2-picolyl)amine (DPA) moieties as the receptor are especially valuable because they bind Zn(II) selectively over intracellular concentrations of $\mathrm{Ca}(\mathrm{II})$. DPA-derivatized, fluorescein-based zinc sensors include the $\mathrm{ZnAF}^{17 \mathrm{j}, \mathrm{k}}$ and $\mathrm{ZP}^{22}$ families of dyes (Figure 1). Because the DPA fragment binds $\mathrm{Zn}$ (II) with a $K_{\mathrm{d}}$ of $70 \mathrm{nM},{ }^{23}$ DPA-appended sensors saturate at low $\mathrm{Zn}$ (II) concentrations. Moreover, $\mathrm{Zn}$ (II) coordination to DPA-derivatized dyes is irreversible on the millisecond time scale of many biological imaging experiments, as demonstrated by the present results and those in ref ${ }^{17} \mathrm{k}$, rendering them poorly suited for reporting time-dependent fluctuations in $\mathrm{Zn}$ (II) levels. Since DPA has a high affinity for other first-row transition metals ions, including $\mathrm{Fe}(\mathrm{II}), \mathrm{Co}$ (II), Ni (II), and $\mathrm{Cu}(\mathrm{II}), \mathrm{Zn}$ (II)-induced fluorescence can be compromised. Because of these shortcomings, the design of fluorescent $\mathrm{Zn}$ (II) chemosensors with alternative metalcoordinating moieties remains an important goal. In particular, it is of interest to install a more weakly zinc-binding unit, which conveys reversibility on the biological (millisecond) time scale, while retaining or improving selectivity for Zn(II). The ZS dyes (Figure 1) were 
developed in our laboratory as a first step toward this goal. ${ }^{24}$ More recently, a series of ZnAF probes having modified pyridylbased metal ion chelates that span a range of dissociation constants were reported. ${ }^{25}$

In the present article we describe new fluorescent Zn(II) chemosensors QZ1 and QZ2, fluorescein-based dyes containing one or two 8-aminoquinoline units on the xanthene moiety, that meet these criteria. QZ1 and QZ2 exhibit a number of advantageous photophysical, thermodynamic, and kinetic properties compared to TSQ and sensors that use DPA for Zn(II) binding. These features include (i) $\mathrm{Zn}$ (II)-specific fluorescence enhancement, (ii) improved selectivity for $\mathrm{Zn}$ (II) over other metal ions as compared to DPA sensors, (iii) micromolar dissociation constants, (iv) reversible $\mathrm{Zn}$ (II) binding, and (v) up to $\sim 150$-fold fluorescence enhancement upon $\mathrm{Zn}$ (II) coordination resulting from both low background fluorescence and highly emissive $\mathrm{Zn}(\mathrm{II})$ complexes.

\section{Experimental Section}

\section{Reagents}

Ethyl acetate was dried over 3-Å molecular sieves. Anhydrous 1,2-dichloroethane (DCE) was purchased from Aldrich and used as received. The xanthene-functionalized fluorescein platforms, 7'-chloro-4'-fluoresceincarboxaldehyde $22 \mathrm{c}(\mathbf{1})$ and $4{ }^{\prime}, 5^{\prime}$ -

fluoresceindicarboxaldehyde ${ }^{22 \mathrm{a}}(\mathbf{2})$, were synthesized as previously described. Sodium triacetoxyborohydride was purchased from Aldrich and 8-aminoquinoline from either Aldrich or Avacado.

\section{Materials and Methods}

Analytical thin-layer chromatography (TLC) was performed on Merck F254 silica gel plates $(0.25 \mathrm{~mm}$ thickness) with UV light visualization. Whatman F254 silica gel-60 plates of $1 \mathrm{~mm}$ thickness were used for preparative TLC. NMR spectra were obtained on a Varian 300 or 500 $\mathrm{MHz}$ spectrophotometer operating at ambient probe temperature, $283 \mathrm{~K}$, and both ${ }^{1} \mathrm{H}$ and ${ }^{13} \mathrm{C}$ NMR spectra were referenced to internal probe standards. IR spectra were obtained on an Avatar 360 FTIR instrument, and samples were prepared as $\mathrm{KBr}$ pellets. High-resolution mass spectrometry was conducted by staff at the MIT Department of Chemistry Instrumentation Facility.

\section{2-[2-Chloro-6-hydroxy-3-oxo-5-(quinolin-8-ylaminomethyl)-3H-xanthen-9-yl]benzoic Acid (3, QZ1)}

To $5 \mathrm{~mL}$ of EtOAc were added 7'-chloro-4'-fluoresceincarboxaldehyde (1, $108 \mathrm{mg}, 0.274$ $\mathrm{mmol}$ ) and 8 -aminoquinoline $(39 \mathrm{mg}, 0.26 \mathrm{mmol})$. The reaction was stirred overnight at room temperature and an orange precipitate formed. The mixture was filtered and the precipitate was suspended in $10 \mathrm{~mL}$ of DCE. A portion $(67 \mathrm{mg}, 0.32 \mathrm{mmol})$ of $\mathrm{NaB}(\mathrm{OAc})_{3} \mathrm{H}$ was added and the reaction was stirred overnight at room temperature, during which time the solution clarified. The solvent was removed under reduced pressure and the crude material was purified by preparative TLC on silica gel $\left(9: 1 \mathrm{CHCl}_{3} / \mathrm{MeOH}\right)$, which afforded pure QZ1 as a magenta solid (53 mg, 38\%): TLC $R_{f}=0.48$ (silica, 9:1 $\mathrm{CHCl}_{3} / \mathrm{MeOH}$ ); mp $>325^{\circ} \mathrm{C}(\mathrm{dec}) ;{ }^{1} \mathrm{H} \mathrm{NMR}$ $\left(\mathrm{CD}_{3} \mathrm{OD}, 300 \mathrm{MHz}\right) \delta 4.80(2 \mathrm{H}, \mathrm{s}), 6.65(2 \mathrm{H}, \mathrm{m}), 6.79(1 \mathrm{H}, \mathrm{s}), 6.92(1 \mathrm{H}, \mathrm{s}), 7.02(1 \mathrm{H}, \mathrm{d}), 7.13$ $(2 \mathrm{H}, \mathrm{m}), 7.33(2 \mathrm{H}, \mathrm{m}), 7.62(2 \mathrm{H}, \mathrm{m}), 8.03(2 \mathrm{H}, \mathrm{m}), 8.61(1 \mathrm{H}, \mathrm{m}) ;{ }^{13} \mathrm{C}$ NMR $\left(\mathrm{DMF}-d_{7}, 125\right.$ MHz) $\delta 49.10,103.53,105.07,108.59,110.01,112.07,112.94,120.34,121.74,123.50,126.49$, $128.08,128.15,128.29,128.58,129.05,129.73,130.20,130.94,134.92,136.08,138.64$, 141.07, 145.79, 146.98, 155.80, 156.96, 170.86, 173.43, 181.03; FTIR (KBr, cm $\left.{ }^{-1}\right) 3416(\mathrm{~s}$, br), $1635(\mathrm{~m}), 1578(\mathrm{~s}), 1516(\mathrm{~m}), 1455(\mathrm{~s}), 1383(\mathrm{~s}), 1340(\mathrm{~m}), 1303(\mathrm{~m}), 1225(\mathrm{w}), 1182(\mathrm{w})$, 1153 (m), 1117 (w), 1087 (w), $1014(\mathrm{~m}), 932$ (w), 880 (w), 824 (w), 790 (w), 715 (w), 685 (w), 628 (w), 599 (w), 548 (w), 469 (w); HRMS (ESI) calcd MH 523.1055, found 523.1061. 


\section{2-[6-Hydroxy-3-oxo-4,5-bis(quinolin-8-ylaminomethyl)-3H-xanthen-9-yl]benzoic Acid (4, QZ2)}

Portions of 8-aminoquinoline (74 mg, $0.51 \mathrm{mmol})$ and dialdehyde $2(100 \mathrm{mg}, 0.250 \mathrm{mmol})$ were combined in $3 \mathrm{~mL}$ of EtOAc and stirred overnight at room temperature. A light orange precipitate formed, the mixture was filtered, and the precipitate was washed with $3 \mathrm{~mL}$ of cold EtOAc. The precipitate was suspended in $4 \mathrm{~mL}$ of $\mathrm{DCE}$, and $\mathrm{NaB}(\mathrm{OAc})_{3} \mathrm{H}(120 \mathrm{mg}, 0.56$ $\mathrm{mmol}$ ) was added. The reaction became dark red and clarified over the course of $\sim 2 \mathrm{~h}$. The reaction was stirred for an additional $12 \mathrm{~h}$ and became orange. Preparative TLC of the reaction on silica gel (20:1 $\left.\mathrm{CHCl}_{3} / \mathrm{MeOH}\right)$ yielded pure QZ2 as a red-orange solid (47 mg, 29\%): TLC $R_{f}=0.47$ (silica, 9:1 $\left.\mathrm{CHCl}_{3} / \mathrm{MeOH}\right) ; \mathrm{mp}>325^{\circ} \mathrm{C}(\mathrm{dec}) ;{ }^{1} \mathrm{H} \mathrm{NMR}\left(\mathrm{CD}_{3} \mathrm{OD}, 300 \mathrm{MHz}\right) \delta 4.67$ $(4 \mathrm{H}, \mathrm{s}), 6.57(2 \mathrm{H}, \mathrm{s}), 6.73(2 \mathrm{H}, \mathrm{d}), 6.92(2 \mathrm{H}, \mathrm{d}), 7.02(2 \mathrm{H}, \mathrm{d}), 7.11-7.16(3 \mathrm{H}, \mathrm{m}), 7.24-7.29$ $(2 \mathrm{H}, \mathrm{m}), 7.51(2 \mathrm{H}, \mathrm{m}), 7.98(3 \mathrm{H}, \mathrm{m}), 8.52(2 \mathrm{H}, \mathrm{d}) ;{ }^{13} \mathrm{C} \mathrm{NMR}\left(\mathrm{CDCl}_{3}, 125 \mathrm{MHz}\right) \delta 37.81$, $107.12,112.81,113.75,115.02,122.33,124.16,129.16,130.00,130.15,130.53,131.16$, 131.66, 134.93, 137.21, 139.83, 141.74, 146.48, 147.81, 158.16, 160.76, 174.66, 181.04; FTIR $\left(\mathrm{KBr}, \mathrm{cm}^{-1}\right) 3046(\mathrm{~s}, \mathrm{br}), 3041(\mathrm{w}), 2950(\mathrm{w}), 2923(\mathrm{w}), 2846(\mathrm{w}), 1638(\mathrm{~m}), 1579(\mathrm{~s}), 1515$ (s), 1442 (s), 1393 (s), 1378 (s), $1330(\mathrm{~s}), 1231$ (w), $1148(\mathrm{~m}), 1095(\mathrm{~m}), 1035(\mathrm{w}), 818(\mathrm{~m})$, $789(\mathrm{~m}), 741(\mathrm{w}), 672(\mathrm{w}), 642(\mathrm{w}), 604(\mathrm{w}), 529(\mathrm{w}), 501(\mathrm{w}), 456(\mathrm{~m})$; HRMS (ESI) calcd $\mathrm{MH}^{+}$645.2132, found 645.2132.

\section{General Spectroscopic Methods}

All aqueous solutions were prepared with Millipore water. Puratonic grade $\mathrm{KCl}$ was purchased from Calbiochem and molecular biology grade piperazine- $N, N^{\prime}$-bis(2-ethanesulfonic acid) (PIPES) from Sigma. With the exception of the $\mathrm{p} K_{\mathrm{a}}$ titrations, measurements were made at $\mathrm{pH}$ 7 in $50 \mathrm{mM}$ PIPES, $100 \mathrm{mM} \mathrm{KCl}$ buffer. Excess ethylenediaminetetraacetic acid (EDTA) was added to solutions of apo QZ for quantum yield and extinction coefficient determination. Zinc stock solutions (100 mM, $500 \mathrm{mM}$ ) were prepared from anhydrous $99.999 \% \mathrm{ZnCl}_{2}$ and water. DMSO stock solutions (1 mM) of QZ1 and QZ2 were prepared, partitioned into $\sim 300-\mu \mathrm{L}$ aliquots, stored at $-25^{\circ} \mathrm{C}$, and thawed in the dark before use. A gradual fluorescence rise is observed when solutions of QZ are allowed to stand for several hours at room temperature in the light. A starting solution of $10 \mathrm{mM} \mathrm{KOH}, 100 \mathrm{mM} \mathrm{KCl}, \mathrm{pH} 12$, was used for $\mathrm{p} K_{\mathrm{a}}$ titrations, and the $\mathrm{pH}$ of the solution was lowered by addition of $6,2,1,0.5$, or $0.1 \mathrm{~N} \mathrm{HCl}$. Quantum yields were measured using fluorescein in $0.1 \mathrm{~N} \mathrm{NaOH}(\Phi=0.95)$ as the standard. ${ }^{26}$ Extinction coefficients were measured over a concentration range of 1-10 $\mu \mathrm{M}$, except for the QZ2:Zn(II) complex, which was studied from 1 to $5 \mu \mathrm{M}$ due to its limited solubility. Experimental details for all spectroscopic measurements performed in this study are available elsewhere. ${ }^{22 \mathrm{c}} \mathrm{A}$ Hitachi F-3010 spectrofluorimeter was used to record emission spectra. Optical absorption spectra were collected with a Cary 1E scanning spectrophotometer or a Hewlett-Packard 8453 diode array spectrophotometer. Circulating water baths were used to maintain all samples at $25 \pm 1^{\circ} \mathrm{C}$. All spectroscopic measurements were repeated a minimum of three times and the resulting averages are reported.

\section{Stopped-Flow Fluorescence Studies}

Single-mixing stopped-flow kinetics studies were performed with a Hi-Tech SF-61 DX2 double-mixing stopped-flow apparatus equipped with a fluorescence detector. Excitation was provided at 505 (ZP1), 492 (ZP3), 495 (ZP4, QZ1), or $490 \mathrm{~nm}$ (QZ2). A GG495 glass cutoff filter $(<455 \mathrm{~nm})$ was placed over the exit to the photomultiplier tube, and emission was monitored from 455 to $700 \mathrm{~nm}$. All solutions were prepared in $50 \mathrm{mM}$ PIPES, $100 \mathrm{mM} \mathrm{KCl}$, $\mathrm{pH}$ 7. Conditions for pseudo-first-order kinetics were maintained by using at least a 10-fold excess of $\mathrm{Zn}(\mathrm{II})$ in all experiments. With the exception of the temperature-dependent studies, all measurements were conducted at $4.3 \pm 0.1^{\circ} \mathrm{C}$ maintained by means of a circulating water bath. The temperature inside the sample chamber was monitored with an internal thermocouple. 
Two series of concentration-dependent studies were performed. To determine the rate constants for $\mathrm{Zn}$ (II) binding to the selected $\mathrm{ZP}$ and QZ dyes, $k_{\mathrm{on}}$, the concentration of $\mathrm{Zn}$ (II) was varied and multiple shots were taken at each $\mathrm{Zn}$ (II) concentration. To ensure that changes in dye concentration did not affect the observed rate constants and that dye aggregation did not occur, a series of experiments where the dye concentration was varied in the presence of at least 10fold excess Zn(II) were also performed. Temperature-dependent studies were conducted to determine the activation enthalpy, $\Delta H^{\ddagger}$, and activation entropy, $\Delta S^{\ddagger}$, associated with $\mathrm{Zn}$ (II) coordination to ZP and QZ dyes. Values for $k_{\text {on }}$ were determined in the presence of excess $\mathrm{Zn}$ (II) at a minimum of five temperatures over a range from $\sim 4$ to $\sim 16{ }^{\circ} \mathrm{C}$ (QZ) or $\sim 4$ to $\sim 40{ }^{\circ} \mathrm{C}$ (ZP). Each experiment was conducted a minimum of three times on different days and with different solutions, and the averages are reported. The observed rate constants obtained from all sets of experiments were calculated by employing the Kinet-Assyst software package (HiTech) to fit individual traces to monoexponentials and averaging the results for individual fits. Details for representative experiments are given as Supporting Information.

\section{Cell Culture}

HeLa cells were cultured in Dulbecco's Modified Eagle Medium (DMEM, Invitrogen) supplemented with $10 \%$ fetal calf serum (FCS, Invitrogen), glutamine ( $2 \mathrm{mM}$ ), penicillin (100 units $/ \mathrm{mL})$, and streptomycin $(100 \mathrm{mg} / \mathrm{mL})$. Two days before imaging, the cells were passed and plated on 10-mm glass coverslips. For labeling, cells were transferred to DMEM containing $1 \% \mathrm{FCS}$ and incubated with $10 \mu \mathrm{M}$ sensor at $37^{\circ} \mathrm{C}$ under $5 \% \mathrm{CO}_{2}$. The cells were washed once with DMEM containing no FCS prior to imaging and/or zinc addition. Zinc was introduced to the cultured cells as the pyrithione salt using a $\mathrm{Zn}$ (II)/pyrithione ratio of 10:2. Stock solutions of $\mathrm{ZnCl}_{2}(10-40 \mathrm{mM})$ and sodium pyrithione (20-80 mM) in DMSO were diluted 10-fold with DMEM prior to addition. In a typical experiment, a $100-\mu \mathrm{L}$ aliquot of this solution was added to the cells bathed in $1 \mathrm{~mL}$ of DMEM. A stock solution of $N, N, N^{\prime}, N^{\prime}$-tetrakis (2-pyridylmethyl)ethylenediamine (TPEN, 10 or $20 \mathrm{mM}$ ) was also diluted 10-fold with DMEM containing no FCS prior to cell treatment. For experiments involving fixed cells, the cells were treated with 4\% PFA ( $1 \mathrm{~mL}$, PBS conaining $4 \%$ PFA and $4 \%$ surcose) for $5 \mathrm{~min}$, washed $3 \times$ $1 \mathrm{~mL}$ with PBS, and mounted onto glass microscope slides using the Vectashield antifading reagent (Vector Labs).

\section{Laser Scanning Confocal Microscopy}

A Zeiss LSM510 microscope equipped with a $63 \times$ objective used (with $1.5 \times$ electronic zoom) was to obtain confocal images. The samples were excited at $488 \mathrm{~nm}$ with an Ar laser. A $z$ series of seven slices taken at depth intervals of $0.75 \mathrm{~nm}$ was acquired for each image. The Metamorph software package was used for quantification.

\section{Two-Photon Microscopy}

Two-photon fluorescence imaging was conducted by using a custom-made two-photon laser scanning microscope based on an Olympus Fluoview 300/BX50WI microscope, equipped with a $60 \times$ objective lens and a 570-nm short-pass emission filter, and a Spectraphysics Tsunami Ti:sapphire laser pumped by Millennia Xs.

\section{Results and Discussion}

\section{Design Considerations}

Several factors were considered in the design of QZ1 and QZ2. Although a number of quinoline-containing fluorescent $\mathrm{Zn}$ (II) sensors exist, 21,27 none of these contain fluorescein as the reporting group. Given the superior photophysical properties of fluorescein and the successful application of quinoline derivatives in biological $\mathrm{Zn}$ (II) sensing, we expected a 
combination of quinoline and fluorescein to be advantageous. Since $\mathrm{Zn}$ (II) concentrations in the synaptic clefts of the hippocampus are presumed to reach near-millimolar concentrations, a $\mathrm{Zn}$ (II)-specific probe with a micromolar dissociation constant arguably should be useful to monitor Zn(II) flux in this region. ${ }^{16 \mathrm{~d}}$ The ZP dyes, although sensitive, bind Zn(II) irreversibly on the biological time scale (vide infra) and with sub-nanomolar dissociation constants, which prohibit their use for monitoring concentration changes in the micromolar to millimolar regime. Reducing the number of donor atoms in the coordination sphere is one way to raise the dissociation constant, which should be achieved by substitution of a $\mathrm{N}_{3} \mathrm{O}$ or $\mathrm{N}_{4} \mathrm{O}$ coordinating unit in the $\mathrm{ZP}$ sensor with a $\mathrm{N}_{2} \mathrm{O}$ donor set. For controlling background fluorescence, a substantial body of work from our laboratory shows that aniline nitrogen atoms generally quench fluorescein emission more efficiently than tertiary amines. ${ }^{22 b, c, e}$ The ligand 8aminoquinoline satisfies these additional criteria. We therefore installed 8-aminoquinoline moieties in the 4'- and 5'-positions of fluorescein to give $\mathrm{N}_{2} \mathrm{O}$ donor sets with aniline-type nitrogen atoms that can act as photoinduced electron transfer (PET) switches.

\section{Syntheses}

Scheme 1 illustrates the syntheses of dyes QZ1 and QZ2 from 8-aminoquinoline and fluorescein aldehyde precursors, the latter of which were prepared in four or five steps according to previously described methodology. ${ }^{22 a, c}$ Condensation of 1 equiv of 8 aminoquinoline with monoaldehyde $\mathbf{1}$ in EtOAc resulted in precipitation of the intermediate imine as an orange solid. Reduction of the imine under mild conditions by using $\mathrm{NaB}$ $(\mathrm{OAc})_{3} \mathrm{H}$ in DCE gave QZ1 in moderate yield following purification by preparative TLC on silica gel with $\mathrm{CHCl}_{3} / \mathrm{MeOH}$ mixtures. QZ2 was obtained by an analogous procedure starting from the symmetrical dialdehyde 2 and 2 equiv of 8-aminoquinoline. Pure QZ1 and QZ2 are both magenta to red-orange solids that are readily soluble in $\mathrm{MeOH}$. Through incorporation of a commercially available ligand moiety, the QZ syntheses are shorter and more economical than those for asymmetric ZP and ZS sensors, where multiple steps are required to assemble the ligand fragments.

\section{Spectroscopic Properties of QZ1}

Table 1 summarizes the results of fluorescence and UV-visible spectroscopic experiments conducted at pH 7 and $100 \mathrm{mM}$ ionic strength (50 mM PIPES, $100 \mathrm{mM} \mathrm{KCl})$ for QZ1 and QZ2. Selected results for the ZP and ZS sensors are included for comparison. Unbound QZ1, in the presence of excess EDTA to scavenge any potentially interfering metal ions, has a quantum yield of $0.024\left(\lambda_{\max }=524 \mathrm{~nm}\right)$. Addition of excess $\mathrm{Zn}$ (II) causes the quantum yield to increase $\sim 33$-fold to $0.78\left(\lambda_{\max }=524 \mathrm{~nm}\right)$. The absorption spectrum undergoes a blue-shift from $505 \mathrm{~nm}\left(\varepsilon=68900 \mathrm{M}^{-1} \mathrm{~cm}^{-1}\right)$ to $498 \mathrm{~nm}\left(\varepsilon=69800 \mathrm{M}^{-1} \mathrm{~cm}^{-1}\right)$ upon $\mathrm{Zn}$ (II) binding, indicating a perturbation of the fluorescein $\pi$ system by presumed $\mathrm{Zn}$ (II) coordination to the phenol. Taken together, there is a $\sim 42$-fold increase in integrated emission resulting from $\mathrm{Zn}$ (II) binding to QZ1 (Figure 2).

The $\mathrm{pH}$ dependence of the QZ1 fluorescence was investigated as shown in Figure 3. QZ1 fluorescence exhibits little change from $\mathrm{pH} \sim 12$ to $\sim 7$ and reaches its maximum at $\mathrm{pH} \sim 5.5$. Two protonation events affect QZ1 fluorescence, with $\mathrm{p} K_{\mathrm{a} 1}=6.1$ and $\mathrm{p} K_{\mathrm{a} 2}=5.0$. The former is assigned to the aniline nitrogen atom, and the latter value corresponds to protonation of the fluorescein and formation of a nonfluorescent state. Less than 2-fold fluorescence change occurs upon protonation of the aniline nitrogen atom compared to $\sim 42$-fold fluorescence enhancement upon $\mathrm{Zn}$ (II) coordination, rendering QZ1 relatively insensitive to $\mathrm{pH}$ changes.

\section{Spectroscopic Properties of QZ2}

QZ2, depicted in Scheme 1, is a symmetrical analogue of QZ1 and contains two 8aminoquinoline moieties. We elected to prepare and characterize QZ2 on the basis of 
experience with several asymmetric and symmetric $\mathrm{Zn}(\mathrm{II})$ sensors previously synthesized in our laboratory. A comparison of the ZS1/ZS3 couple (Figure 1) shows that installation of a second tertiary amine-based ligand on the xanthene framework results in a substantial decrease in background fluorescence (symmetric ZS1 $\Phi_{\text {free }}=0.50$; asymmetric ZS3 $\Phi_{\text {free }}=0.71$ ) ${ }^{24} \mathrm{~A}$ similar trend occurs for DPA-based ZP1 and its asymmetric analogue. ${ }^{28}$ Such "cooperative quenching" has recently been documented in $N$-arylpiperazine-substituted 2',7'-

dichlorofluoresceins. ${ }^{29}$ This behavior makes intuitive sense when the simple PET quenching mechanism is considered. ${ }^{30}$ According to this model, a free nitrogen lone pair quenches the metal-free dyes by electron transfer into the hole produced during photoexcitation. Given that symmetrical sensors have two nitrogen lone pairs available to quench the fluorophore excited state, compared to only one nitrogen lone pair in the asymmetrical analogues, relatively less background fluorescence is expected. We reasoned that a symmetric QZ dye would exhibit even further reduced background fluorescence than asymmetrical QZ1 while maintaining the high degree of Zn(II)-induced turn-on exhibited by QZ1.

In accord with this expectation, apo QZ2 has a very low quantum yield of $0.005\left(\lambda_{\max } \approx 520\right.$ $\mathrm{nm})$ at $\mathrm{pH} 7(50 \mathrm{mM}$ PIPES, $100 \mathrm{mM} \mathrm{KCl})$ and in the presence of EDTA to complex any potentially interfering metal ions (Table 1 ). An $\sim 150$-fold fluorescence increase occurs upon introduction of excess $\mathrm{Zn}(\mathrm{II})$ to a solution of QZ2 (Figure 2), and the quantum yield for the $\mathrm{Zn}$ (II)-bound complex is $0.70\left(\lambda_{\max }=518 \mathrm{~nm}\right)$. The absorption spectrum of QZ2 blue-shifts by $10 \mathrm{~nm}$ upon $\mathrm{Zn}(\mathrm{II})$ coordination, moving from $499 \mathrm{~nm}\left(\varepsilon=37200 \mathrm{M}^{-1} \mathrm{~cm}^{-1}\right)$ to $489 \mathrm{~nm}(\varepsilon=$ $33600 \mathrm{M}^{-1} \mathrm{~cm}^{-1}$ ). This blue-shift reflects a perturbation of the fluorescein $\pi$ system and is consistent with the phenol oxygen atom being involved in $\mathrm{Zn}$ (II) binding. The relatively low extinction coefficients of QZ2 are reminiscent of those determined for the fluorescein-based, DPA-derivatized Zn(II) sensor ZP2 (Table 1) and can be rationalized on the basis of the nature of the fluorescein chromophore. Unsubstituted fluorescein has an extinction coefficient of $\sim 77000 \mathrm{M}^{-1} \mathrm{~cm}^{-1}(0.1 \mathrm{~N} \mathrm{NaOH}),{ }^{31}$ and fluoresceins halogenated in the $2^{\prime}$ - and 7 '-positions exhibitmore intense absorption. For instance, the reported extinction coefficient for $2^{\prime}, 7^{\prime}$ dichlorofluorescein is $101000 \mathrm{M}^{-1} \mathrm{~cm}^{-1}(0.1 \mathrm{~N} \mathrm{NaOH}) .{ }^{32}$ Relative extinction coefficients for our dyes with and without chloro substitution in these positions (ZP1/ZP2, QZ1/QZ2) reflect this trend.

Figure 3 includes a representative $\mathrm{p} K_{\mathrm{a}}$ titration of QZ2, which shows that two protonation events influence QZ2 emission. The $\mathrm{p} K_{\mathrm{a}}$ values of 7.0 and 4.9 are assigned to aniline nitrogen and fluorescein protonation, respectively. Only $\sim 2$-fold fluorescence enhancement occurs upon protonation of the aniline nitrogen atom, compared to the $\sim 150$-fold fluorescence increase associated with $\mathrm{Zn}$ (II) coordination, which indicates that QZ2 fluorescence is also virtually insensitive to protons. This feature is an improvement over symmetric sensors ZP1-3, which display greater degrees of proton-induced fluorescence turn-on. It is also relevant to biological imaging studies, where changes in proton concentration may occur and potentially interfere with the $\mathrm{Zn}(\mathrm{II})$ response of a proton-sensitive dye.

\section{Metal-Binding Properties of QZ1 and QZ2}

The acquisition of molecules with varying dissociation constants $\left(K_{\mathrm{d}}\right)$ is an important goal in biological Zn(II) sensor development. Since near-millimolar concentrations of $\mathrm{Zn}$ (II) are presumed to exist in synaptic clefts located in substructures of the mammalian hippocampus, fluorescent $\mathrm{Zn}$ (II) sensors with $K_{\mathrm{d}}$ values in the mid- to high-micromolar range will be advantageous for imaging this pool. Investigations of Zn(II) pathology involving high influx levels of $\mathrm{Zn}$ (II) could also benefit from such low-affinity chemosensors. In contrast to the ZP sensor family, members of which bind Zn(II) with subnanomolar affinity, QZ1 and QZ2 exhibit maximum fluorescence response in the presence of high-micromolar to millimolar concentrations of $\mathrm{Zn}$ (II). Metal binding titrations monitored by fluorescence spectroscopy 
revealed that QZ1 gives maximum emission in the presence of $\sim 300 \mu \mathrm{M} \mathrm{Zn(II),} \mathrm{with} \mathrm{an}$ apparent $K_{\mathrm{d}}$ value of $33 \pm 2 \mu \mathrm{M}$ at $25^{\circ} \mathrm{C}$ (Figure 2 and Figure S1, Supporting Information). A similar value, $48 \pm 3 \mu \mathrm{M}$, was obtained from stopped-flow kinetic studies performed at $4.3^{\circ}$ $\mathrm{C}$ (see below). Sensor QZ2 can coordinate two Zn(II) ions and responds to even higher concentrations of $\mathrm{Zn}(\mathrm{II})$. Fluorescence titrations reveal that $\sim 50 \%$ of the total fluorescence increase occurs when QZ2 encounters $\sim 770 \mu \mathrm{M} \mathrm{Zn}$ (II), and low-millimolar concentrations are required to achieve full fluorescence enhancement (Figure 2 and Figure S1). Stopped-flow kinetic experiments (see Figure 6 and discussion below) indicate a $K_{\mathrm{d} 1}$ value of $41 \pm 3 \mu \mathrm{M}$ for $\mathrm{Zn}$ (II) binding to QZ2 at $4.3^{\circ} \mathrm{C}$, comparable to that of QZ1. As anticipated from the micromolar affinity of each QZ dye for $\mathrm{Zn}$ (II), the metal ion binding events are readily reversible. Addition of the heavy metal chelator TPEN to solutions of QZ and Zn(II) decreases the fluorescence to baseline immediately upon mixing (Figure $\mathrm{S} 2$ ).

The coordination of QZ1 and QZ2 to Zn(II) was also explored by using UV-visible spectroscopy. The absorption spectra of both dyes are dominated by the fluorescein chromophore, as anticipated, and slight ( $10 \mathrm{~nm}$ ) blue-shifts in absorption occur upon $\mathrm{Zn}$ (II) binding. The resulting difference spectra for the QZ dyes are comparable to those obtained for members of the ZP family and presumably reflect a similar perturbation to the fluorescein $\pi$ system resulting from $\mathrm{Zn}(\mathrm{II})$ coordination, attributed to phenol coordination. ${ }^{22 \mathrm{a}}$ For QZ1, Zn (II) coordination results in an absorption increase at $492 \mathrm{~nm}$ and decreases at 513 and $250 \mathrm{~nm}$ (Figure 4). Less prominent features are observed at 460, 317, and $283 \mathrm{~nm}$. The difference spectrum for QZ2 has analogous features, with an absorption increase at $482 \mathrm{~nm}$ and a decrease at $504 \mathrm{~nm}$.

QZ1 was designed to bind Zn(II) with 1:1 stoichiometry. Fluorescence spectroscopy was employed to verify the solution stoichiometry of the QZ1:Zn(II) complex. Job plot analyses revealed a break at 0.5 , indicating formation of a 1:1 species in solution (Figure S3). This feature may be beneficial for calibration purposes in vivo. Since $\mathrm{Zn}$ (II) forms four-, five-, and six-coordinate complexes, we propose that one or more water molecules or buffer components complete the $\mathrm{Zn}$ (II) coordination sphere defined by the $\mathrm{N}_{2} \mathrm{O}$ donor set of the QZ ligand system. Given the two 8-aminoquinoline moieties, QZ2 can bind one or two Zn(II) ions, depending on the concentration of $\mathrm{Zn}$ (II) in solution. The second $\mathrm{Zn}$ (II)-binding event is of significantly lower affinity, because millimolar $\mathrm{Zn}(\mathrm{II})$ is required for saturation (Figure 2 and Figure S1); its $K_{\mathrm{d}}$ value was not determined.

\section{Zn(II) Selectivity of QZ1 and QZ2}

One challenge in $\mathrm{Zn}$ (II) sensor development is to procure systems that are selective for $\mathrm{Zn}$ (II) over a wide range of potentially competing metal ions. DPA is a valuable ligand for biological $\mathrm{Zn}$ (II) sensing because of its high affinity for $\mathrm{Zn}$ (II) over $\mathrm{Ca}(\mathrm{II})$, but dyes containing this ligand moiety readily bind other divalent metal ions that block $\mathrm{Zn}$ (II) coordination. Fluorescence spectroscopy was employed to investigate the selectivity of QZ1 and QZ2 for Zn(II) over biologically relevant alkali and alkaline earth metals, divalent first-row transition metals, $\mathrm{Cd}$ (II), and $\mathrm{Hg}$ (II); representative data for QZ2 are shown in Figure 5 (see Figure S3 for QZ1 data). QZ1 and QZ2 readily detect Zn(II) in the presence of millimolar concentrations of $\mathrm{Na}$ (I), $\mathrm{K}(\mathrm{I}), \mathrm{Ca}(\mathrm{II})$, and $\mathrm{Mg}(\mathrm{II})$, indicating that these physiologically relevant components will not interfere with QZ detection of Zn(II) in such samples. Of the first-row transition metals considered, only $\mathrm{Ni}$ (II) and $\mathrm{Cu}$ (II) compromise the $\mathrm{Zn}$ (II)-induced fluorescence enhancement of the QZ sensors. This selectivity is a substantial advantage over ZP1-8, which preferentially bind $\mathrm{Fe}$ (II) and $\mathrm{Co}$ (II) in addition to $\mathrm{Ni}$ (II) and $\mathrm{Cu}$ (II). The QZ chemosensors also differentiate $\mathrm{Zn}$ (II) from Cd(II). Complexation to Cd(II) results in only negligible fluoresence enhancement, and $\mathrm{Zn}$ (II) readily displaces $\mathrm{Cd}$ (II) from the metal ion coordination sphere. This behavior 
contrasts with that of the ZP and ZS dyes, which show comparable turn-on for both $\mathrm{Zn}$ (II) and $\mathrm{Cd}(\mathrm{II}) .{ }^{22} \mathrm{c},{ }^{24}$

\section{Kinetic Investigations of ZP and QZ Sensors}

The fluorescence response of the $\mathrm{ZP}$ and QZ dyes to zinc can be observed by the eye or with a hand-held UV lamp to occur immediately upon mixing. Stopped-flow fluorescence studies were therefore conducted to measure the rate constants for $\mathrm{Zn}$ (II) association, via fluorescence turn-on, for QZ1, QZ2, and several representative ZP dyes. Rate constants for Zn(II) dissociation were either measured (QZ) or calculated (ZP) from $k_{\text {on }}$ and experimentally determined dissociation constants. Equations 1 and 2 illustrate the relationship between the dissociation constant, $K_{\mathrm{d}}$, the rate constants for $\mathrm{Zn}$ (II) binding, $k_{\mathrm{on}}$, and $\mathrm{Zn}$ (II) release, $k_{\mathrm{off}}$, and the observed pseudo-first-order rate constant, $k_{\mathrm{obs}}$. To verify that $k_{\mathrm{obs}}$ is independent of initial dye concentration,

$$
\begin{gathered}
k_{\text {obs }}=k_{\text {on }}[\mathrm{Zn}(\mathrm{II})]+k_{\text {off }} \\
K_{\mathrm{d}}=k_{\text {off }} / k_{\text {on }}
\end{gathered}
$$

a series of experiments were conducted where the dye concentration (after mixing) was varied from 0.5 to $5 \mu \mathrm{M}$ in the presence of at least 10 -fold excess $\mathrm{Zn}(\mathrm{II})$; the results are detailed in the Supporting Information. For each dye, this experiment showed that $k_{\mathrm{obs}}$ is independent of initial dye concentration, which confirmed that dye aggregation or other potentially interfering phenomena were not occurring during the course of the experiment.

Given the subnanomolar dissociation constants of the ZP dyes, essentially no back-reaction is observed on the time scale of the stopped-flow measurements, and eq 1 can be simplified to eq 3. Plots of $k_{\mathrm{obs}}$ vs $\mathrm{Zn}$ (II) concentration for $\mathrm{Zn}$ (II) binding to

$$
k_{\text {obs }}=k_{\text {on }}[\mathrm{Zn}(\mathrm{II})]
$$

the selected ZP dyes illustrate this notion since the lines pass through the origin (Figure 6). The data in Table 2 show that ZP dyes are characterized by $k_{\text {on }}$ values in the range of (6.3-8.5) $\times 10^{5} \mathrm{M}^{-1} \mathrm{~s}^{-1}$ at $4.3^{\circ} \mathrm{C}$. Kinetic data from temperature-dependent studies (see Figure 8 and discussion below) afford $k_{\text {on }}$ values of (3.3-5.2) $\times 10^{6} \mathrm{M}^{-1} \mathrm{~s}^{-1}$ at $25^{\circ} \mathrm{C}$ for the ZP sensors. These association constants indicate that the $\mathrm{ZP}$ dyes can respond to $\mathrm{Zn}$ (II) on the millisecond time scale and are similar to those obtained for the $\mathrm{ZnAF}$ dyes $\left((3.1-4.3) \times 10^{6} \mathrm{M}^{-1} \mathrm{~s}^{-1}\right.$ at $\left.25^{\circ} \mathrm{C}\right)$, which also utilize DPA as the $\mathrm{Zn}(\mathrm{II})$ chelate. ${ }^{17 \mathrm{k}}$ Association rates for fluorescent macrocyclebased $\mathrm{Zn}(\mathrm{II})$ sensors are notably slower, generally exhibiting $k_{\mathrm{on}}$ values of $10-10^{2} \mathrm{M}^{-1} \mathrm{~s}^{-1}$,

$17 \mathrm{~h}$ due to the rigidity of the ligand moiety. ${ }^{17 \mathrm{e}, \mathrm{h}}$ Members of the $\mathrm{ZP}$ family display rapid $\mathrm{Zn}$ (II) complexation and, as calculated from the $K_{\mathrm{d}}$ and $k_{\text {on }}$ values, relatively slow $\mathrm{Zn}$ (II) dissociation. The latter feature will be prohibitive for many imaging applications. Equation 2

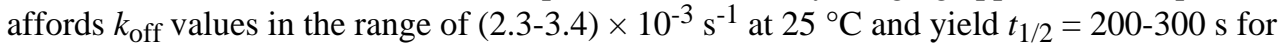
$\mathrm{Zn}(\mathrm{II})$ dissociation from $\mathrm{ZP}$.

In contrast, the QZ dyes display readily reversible $\mathrm{Zn}(\mathrm{II})$ coordination. The kinetic data for QZ1 and QZ2 depicted in Figure 6 yield $k_{\text {on }}$ values of (3.1-3.9) $\times 10^{6} \mathrm{M}^{-1} \mathrm{~s}^{-1}$ at $4.3{ }^{\circ} \mathrm{C}$, indicating faster $\mathrm{Zn}$ (II) complexation as compared to $\mathrm{ZP}$, and return $k_{\text {off }}$ values of 150 and 160 $\mathrm{s}^{-1}$, respectively, at this temperature. Given the fast association rates observed for QZ, we were unable to obtain reliable kinetic data above $16^{\circ} \mathrm{C}$. Extrapolation of the Eyring plots in Figure 7 yields estimated $k_{\text {on }}$ values of $3.7 \times 10^{7}$ and $4.5 \times 10^{7} \mathrm{M}^{-1} \mathrm{~s}^{-1}$ and $k_{\text {off }}$ values of $>10^{3} \mathrm{~s}^{-1}$ for QZ1 and QZ2 at $25^{\circ} \mathrm{C}$. These computed $k_{\text {off }}$ values are over 5 orders of magnitude greater than those observed for the $\mathrm{ZP}$ and $\mathrm{ZnAF}$ systems and yield $t_{1 / 2}<0.5 \mathrm{~ms}$. The QZ dissociation rates are greater than those of Fura-2, Indo-1, and Quin-2, fluorescent $\mathrm{Ca}$ (II) sensors that have been successfully used to measure $\mathrm{Ca}$ (II) changes in biological specimens. ${ }^{33}$ This feature 
makes the QZ dyes potentially useful for biological studies that involve monitoring Zn(II) flux, such as those proposed to occur at synapses.

The fast association rates for Zn(II) complexation to QZ1 and QZ2 necessitated lowtemperature stopped-flow investigations. To ascertain the effect of temperature on the association rate, a series of temperature variation experiments were conducted and are detailed in the Supporting Information. Figure 7 illustrates the Eyring plots for the ZP and QZ dyes under study. Values for the activation enthalpy, $\Delta H^{\ddagger}$, and activation entropy, $\Delta S^{\ddagger}$, associated with $\mathrm{Zn}$ (II) binding are given in Table 2. The ZP and QZ dyes all have $\Delta H^{\ddagger}$ between 10.7 and $12.5 \mathrm{kcal} / \mathrm{mol}$, which reflects a relatively low activation barrier and fast rate of association. Values for $\Delta S^{\ddagger}$ are positive and range from 10.7 to $13.2 \mathrm{cal} / \mathrm{mol} \cdot \mathrm{K}$. The positive $\Delta S^{\ddagger}$ values may be due to dissociation of buffer components from the reacting species in the transition state.

\section{Comparison of QZ to ZP and Other Fluorescent Zn(II) Sensors}

A comparison of spectroscopic and photophysical features of the QZ vs the ZP and ZS dyes reveals some expected similarities and several striking differences (Table 1). With the exception of ZP5, the asymmetrical aniline-derivatized ZP dyes, ZP4-8, have $\Phi_{\text {free }}<0.1$, the latter of which is attributed to PET quenching of the fluorescein excited state at physiological $\mathrm{pH}$ by the aniline nitrogen lone pair. ${ }^{22 \mathrm{c}}$ The quantum efficiency of QZ1 is 2.5 -fold lower than that of asymmetrical ZP4 $\left(\Phi_{\text {free }}=0.06\right)^{22 b, c}$ and comparable to that of ZP8 $\left(\Phi_{\text {free }}=0.03\right)$, $22 \mathrm{e}$ an asymmetrical ZP dye based on 2',7'-difluorofluorescein. Because of the addition of a second quenching moiety, symmetric QZ2 shows an even more pronounced reduction in background fluorescence, with $\Phi_{\text {free }}=0.005$. This value is comparable to the quantum yields for select benzoate-substituted ZnAF dyes ${ }^{17 \mathrm{k}}$ and represents a $\sim 76$-fold reduction in background fluorescence relative to our first Zn(II) responsive dye, ZP1 (Figure 8; Figure S20 displays a comparison of the emission spectra for the $\mathrm{Zn}(\mathrm{II})$-bound sensors). ${ }^{22 \mathrm{a}}$

In addition to reducing background fluorescence significantly, Zn(II) binding to QZ1 and QZ2 efficiently alleviates PET quenching and restores $75-85 \%$ of fluorescein emission $\left(\mathrm{QZ1}, \Phi_{\mathrm{Zn}}\right.$ $=0.78 ; \mathrm{QZ2}, \Phi_{\mathrm{Zn}}=0.70$ ). This behavior greatly contrasts with the turn-on observed for the aniline-derivatized ZP4-type dyes, where fluorescein emission remains substantially quenched following Zn(II) coordination (ZP4 and ZP8, $\Phi_{\mathrm{Zn}} 0.3$ ). Taken together, QZ1 and QZ2 offer significantly enhanced dynamic ranges, $\sim 42$ - and $\sim 150$-fold respectively, as compared to the ZP and ZS sensors previously reported (Table 1 ) as well as a number of commercially available $\mathrm{Zn}$ (II) sensors such as Newport Green. ${ }^{17 i}$ QZ2 also shows greater fluorescence en-hancement than the benzoate-functionalized ZnAF dyes which, like ZP4-8, suffer from partially quenched fluorescein emission in the $\mathrm{Zn}$ (II)-bound forms. Because the fluorescein platform of QZ2 is not halogenated, which lowers the molar absorptivity, the brightness $(\Phi \times \varepsilon)$ of the $\mathrm{Zn}$ (II)bound species is less than those of ZP1 and ZP3 and similar to that of ZP4 (Figure S19). Incorporation of chloro or fluoro substituents in the 2'- and 7'-positions of the QZ2 fluorophore platform would increase brightness and maintain a QZ2-like dynamic range; however, this modification is unnecessary because QZ2 is readily detectable in vivo (vide infra).

\section{Confocal Imaging and Zn(II) Response in Vivo}

Preliminary confocal imaging experiments established that QZ1 and QZ2 are membrane permeable. Given the micromolar $K_{\mathrm{d}}$ value of QZ for $\mathrm{Zn}(\mathrm{II})$, we conducted solution studies (50 mM PIPES, $100 \mathrm{mM} \mathrm{KCl}, \mathrm{pH}$ 7) to determine whether QZ and pyrithione, an ionophore that delivers $\mathrm{Zn}$ (II) into cells, compete for $\mathrm{Zn}$ (II). Addition of excess 1:2 Zn(II)/pyrithione to QZ resulted in negligible fluorescence change, in agreement with the reported $K_{\mathrm{d}}$ of $\sim 10^{-11} \mathrm{M}$ for formation of the $1: 2 \mathrm{Zn} /$ pyrithione complex. ${ }^{34}$ In vivo experiments were subsequently conducted by treating HeLa cells with $10 \mu \mathrm{M}$ QZ2 and $100 \mu \mathrm{M} \mathrm{Zn}(\mathrm{II})$ with varying 
concentrations $(0.5-30 \mu \mathrm{M})$ of pyrithione. This study indicated that substoichiometric pyrithione delivers $\mathrm{Zn}(\mathrm{II})$ into HeLa cells (data not shown, ascertained by fluorescence microscopy), and we therefore employed a 10:2 Zn(II)/pyrithione ratio for all subsequent imaging experiments. Similar results were obtained in a study where the fluorescence response of Zinquin-treated chronic lymphocytic leukemia cells was monitored as a function of varying $\mathrm{Zn}(\mathrm{II}) /$ pyrithione ratios. ${ }^{21 \mathrm{~g}}$ Further control experiments indicated that the $\mathrm{Zn}(\mathrm{II})$-induced fluorescence enhancement of QZ2 is reversible by addition of TPEN to the cell culture medium (Figure S21).

Of particular interest is the use of intracellular $\mathrm{Zn}$ (II) sensors with varying $K_{\mathrm{d}}$ values to report on a range of $\mathrm{Zn}$ (II) concentrations in cells. To illustrate the utility of a relatively low affinity $\mathrm{Zn}(\mathrm{II})$ sensor in vivo, we compared the responses of $\mathrm{ZP} 3$ and QZ2 to varying intracellular concentrations of $\mathrm{Zn}$ (II). Figure 9 displays HeLa cells treated with $10 \mu \mathrm{M}$ dye and 0, 50, 100, or $200 \mu \mathrm{M}$ total $\mathrm{Zn}$ (II). ZP3, which has a $K_{\mathrm{d}}$ of $0.7 \mathrm{nM}$ for $\mathrm{Zn}$ (II), shows saturation behavior when $50 \mu \mathrm{M} Z \mathrm{Zn}(\mathrm{II})$ is added to the cell culture medium. In contrast, the fluorescence intensity of cells treated with QZ2, characterized by a micromolar $K_{\mathrm{d}}$ for $\mathrm{Zn}$ (II), increases upon addition of up to $200 \mu \mathrm{M} \mathrm{Zn(II).} \mathrm{Wedid} \mathrm{not} \mathrm{exceed} \mathrm{this} \mathrm{value} \mathrm{to} \mathrm{avoid} \mathrm{Zn}$ (II) toxicity. Although the intracellular concentration of $\mathrm{Zn}$ (II) is unclear because substoichiometric pyrithione was used, the results displayed in Figure 9 indicate that probe affinity is an important parameter for in vivo metal ion detection and that lower affinity sensors can be employed to report on relatively high concentrations of the analyte in vivo. This observation is in good agreement with a recent report in which $\mathrm{ZnAF}$ sensors with modified DPA ligands showed $K_{\mathrm{d}}$-dependent $\mathrm{Zn}$ (II) responses in vivo 25 and contrasts with a study concluding that relative dye affinity is unimportant for in vivo $\mathrm{Zn}(\mathrm{II})$ detection. ${ }^{35}$ We note that $\mathrm{ZP} 3$ and $\mathrm{QZ2}$ show different staining patterns in HeLa cells, with ZP3 localizing to the Golgi apparatus ${ }^{22 \mathrm{a}}$ and QZ2 showing a more diffuse pattern.

We next investigated ZP3 and QZ2 staining of acute hippocampal slices from adult rat, substructures of which contain histochemically observable zinc. Whereas ZP3 vividly stained the DG and CA3 regions of the hippcampus, ${ }^{22 \mathrm{~d}}$ no differential staining was observed following treatment with either QZ1 or QZ2 (Figure S22). This comparison suggests that the levels of endogenous and histochemically observable $\mathrm{Zn}$ (II) in the DG and CA3 regions of the rat hippocampus are between the detection limits of ZP3 $\left(K_{\mathrm{d}}<1 \mathrm{nM}\right)$ and QZ $\left(K_{\mathrm{d}} \approx 40 \mu \mathrm{M}\right)$ and further illustrates the utility of $\mathrm{Zn}$ (II) sensors with varying dissociation constants for analyzing mobile $\mathrm{Zn}$ (II) concentrations in vivo.

\section{Biological Imaging with Two-Photon Microscopy}

The development and implementation of new optical imaging techniques parallels advances in chemosensor design. Of recent interest is the application of two-photon microscopy (TPM) to biological $\mathrm{Zn}(\mathrm{II})$ imaging. ${ }^{18 \mathrm{c}, 22 \mathrm{e}}$ Optical imaging by TPM offers some advantages over conventional one-photon techniques. ${ }^{36}$ By employing two photons of lower energy, laser excitation typically causes less photodamage to dyes and biological samples, and allows for penetration of thicker specimens.

To ascertain the ability of QZ1 and QZ2 to undergo two-photon excitation, the fluorescence intensity of buffered solutions of $10 \mu \mathrm{M}$ QZ and excess Zn(II) (50 mM PIPES, $100 \mathrm{mM} \mathrm{KCl}$, $\mathrm{pH} 7$ ) was evaluated following two-photon excitation over the $740-880 \mathrm{~nm}$ range. Figure 10 (left panel) displays the relative fluorescence intensity of these solutions and reveals that maximum emission occurs with excitation at $780 \mathrm{~nm}$. Live HeLa cells treated with QZ2 and $\mathrm{Zn}$ (II) were imaged by TPM with excitation at $780 \mathrm{~nm}$ and are also depicted in Figure 10 (see Figure S23 for a complete set of images), establishing that QZ2 responds to two-photon excitation in vivo. 


\section{Summary}

The preparation and photophysical characterization of 8-aminoquinline-derivatized, fluorescein-based Zn(II) sensors QZ1 and QZ2 are presented. These dyes have dissociation constants for $\mathrm{Zn}(\mathrm{II})$ in the micromolar range, can readily detect $\mathrm{Zn}$ (II) in the presence of biologically relevant concentrations of $\mathrm{Na}(\mathrm{I}), \mathrm{K}(\mathrm{I}), \mathrm{Mg}(\mathrm{II})$, and $\mathrm{Ca}(\mathrm{II})$, and display superior selectivity for $\mathrm{Zn}$ (II) as compared to other known fluorescent $\mathrm{Zn}$ (II) probes. Stopped-flow kinetic analyses show that the QZ dyes display rapid and reversible Zn(II) binding, which affords high temporal resolution and contrasts to the slow dissociation of $\mathrm{Zn}$ (II) observed for $\mathrm{ZP}$ and other DPA-containing sensors. The results suggest that QZ-type systems will be valuable for biological imaging of $\mathrm{Zn}$ (II) flux at elevated concentrations. Because of low background fluorescence and efficient alleviation of PET quenching with $\mathrm{Zn}$ (II) coordination, QZ1 and QZ2 afford excellent $~ 42$ - and 150-fold fluorescence enhancement upon Zn(II) binding. A comparison of the photophysical properties of QZ to those of ZP and ZS systems indicates that the nature of the PET switching nitrogen atom is not the only determining factor for fluorescence behavior. Rather, properties of the entire ligand fragment modulate both the degree of fluorescein quenching and the amount of fluorescence turn-on that results from analyte recognition. Quantum calculations will be employed to investigate this matter further. Finally, single-photon and multiphoton microscopy reveal that QZ are cell-permeable and Zn (II)-responsive in vivo. Comparison of the response of QZ2 (micromolar $K_{\mathrm{d}}$ ) to that of ZP3 (subnanomolar $K_{\mathrm{d}}$ ) to intracellular zinc indicates that sensor binding affinity plays a significant role in metal ion detection in vivo. Efforts to prepare new and utilize current QZ sensors for neurobiological imaging applications are in progress.

\section{Supplementary Material}

Refer to Web version on PubMed Central for supplementary material.

\section{Acknowledgements}

This work was supported by Grant GM65519 from the National Institute of General Medical Sciences. Spectroscopic instrumentation at the MIT DCIF is maintained with funding from NIH Grant 1S10RR-13886-01 and NSF Grants CH3-9808063, DBI9729592, and CHE-9808061. M.S. is an Investigator at the Howard Hughes Medical Institute. E.M.N. thanks NDSEG for a graduate fellowship, Drs. C. J. Chang and D. Xu for insightful discussions, and Dr. L. G. Beauvais for assistance with the stopped-flow experiments.

\section{References}

1. Vallee BL, Falchuk KH. Physiol. ReV. 1993;73:79-118. [PubMed: 8419966]

2. Walker CF, Black RE. Annu. ReV. Nutr. 2004;24:255-275. [PubMed: 15189121]

3. (a) Daiyasu H, Osaka K, Ishino Y, Toh H. FEBS Lett 2001;503:1-6. [PubMed: 11513844] (b) Ho E, Ames BN. Proc. Natl. Acad. Sci. U.S.A 2002;99:16770-16775. [PubMed: 12481036]

4. (a) Truong-Tran AQ, Carter J, Ruffin RE, Zalewski PD. Biometals 2001;14:315-330. [PubMed: 11831462] (b) Kimura E, Aoki S, Kikuta E, Koike T. Proc. Natl. Acad. Sci. U.S.A 2003;100:37313736. [PubMed: 12646703]

5. (a) Frederickson CJ. Int. ReV. Neurobiol. 1989;31:145-238. [PubMed: 2689380] (b) Huang EP. Proc. Natl. Acad. Sci. U.S.A 1997;94:13386-13387. [PubMed: 9391032] (c) Frederickson CJ, Bush AI. Biometals 2001;14:353-366. [PubMed: 11831465] (d) Takeda A. Biometals 2001;14:343-351. [PubMed: 11831464] (e) Manzerra P, Behrens MM, Canzoniero LMT, Wang XQ, Heidinger V, Ichinose T, Yu SP, Choi DW. Proc. Natl. Acad. Sci. U.S.A 2001;98:11055-11061. [PubMed: 11572968]

6. (a) Liuzzi JP, Cousins RJ. Annu. ReV. Nutr. 2004;24:151-172. [PubMed: 15189117] (b) Valente T, Auladell C. Mol. Cell. Neurosci 2002;21:189-204. [PubMed: 12401442] (c) Cole TB, Wenzel HJ, Kafer KE, Schwartzkroin PA, Palmiter RD. Proc. Natl. Acad. Sci. U.S.A 1999;96:1716-1721. 
[PubMed: 9990090] (d) Lee J-Y, Cole TB, Palmiter RD, Koh J-Y. J. Neurosci 2000;20:RC79 1-5. [PubMed: 10807937]

7. (a) Jacob C, Maret W, Vallee BL. Proc. Natl. Acad. Sci. U.S.A 1998;95:3489-3494. [PubMed: 9520393] (b) Ebadi M, Iversen PL, Hao R, Cerutis DR, Rojas P, Happe HK, Murrin LC, Pfeiffer RF. Neurochem. Int 1995;27:1-22. [PubMed: 7655341] (c) Maret W. BioMetals 2001;14:187-190. (d) Knipp M, Meloni G, Roschitzki B, Vasák M. Biochemistry 2005;44:3159-3165. [PubMed: 15736926]

8. (a) Qian W-J, Gee KR, Kennedy RT. Anal. Chem 2003;75:3468-3475. [PubMed: 14570199] (b) Qian W-J, Peters JL, Dahlgren GM, Gee KR, Kennedy RT. BioTechniques 2004;37:922-933. [PubMed: 15597541]

9. (a) Vogt K, Mellor J, Tong G, Nicoll R. Neuron 2000;26:187-196. [PubMed: 10798403] (b) Howell GA, Welch MG, Frederickson CJ. Nature 1984;308:736-738. [PubMed: 6717567]

10. (a) Kay AR. J. Neurosci 2003;23:6847-6855. [PubMed: 12890779] (b) Takeda A. Brain Res. ReV. 2000;34:137-148. [PubMed: 11113504] (c) Li YV, Hough CJ, Sarvey JM. Science STKE 2003:19. (d) Li Y, Hough CJ, Suh SW, Sarvey JM, Frederickson CJ. J. Neurophysiol 2001;86:2597-2604. [PubMed: 11698545]

11. (a) Choi DW, Koh JY. Annu. ReV. Neurosci. 1998;21:347-375. [PubMed: 9530500] (b) Frederickson CJ, Maret W, Cuajungco MP. The Neuroscientist 2004;10:18-25. [PubMed: 14987444]

12. García-Colunga J, Vázquez-Gómez E, Miledi R. Pharmacogenomics J 2004;4:388-393. [PubMed: 15354177]

13. Chausmer AB. J. Am. Coll. Nutr 1998;17:109-115. [PubMed: 9550453]

14. Henshall SM, et al. Oncogene 2003;22:6005-6012. [PubMed: 12955079]

15. (a) Cuajungco MP, Lees GJ. Neurobiol. Dis 1997;4:137-169. [PubMed: 9361293] (b) Bush AI. Trends Neurosci 2003;26:207-214. [PubMed: 12689772] (c) Bush AI. Alzheimer Dis. Assoc. Disord 2003;17:147-150. [PubMed: 14512827] (d) Suh SW, Jensen KB, Jensen MS, Silva DS, Kesslak PJ, Danscher G, Frederickson CJ. Brain Res 2000;852:274-278. [PubMed: 10678753]

16. (a) Kimura E, Koike T. Chem. Soc. ReV. 1998;27:179-184. (b) Lim NC, Freake HC, Brückner C. Chem. Eur. J 2005;11:38-49. (c) Jiang P, Guo Z. Coord. Chem. ReV. 2004;248:205-229. (d) Frederickson C. Science STKE 2003:18. (e) Kikuchi K, Komatsu K, Nagano T. Curr. Opin. Chem. Biol 2004;8:182-191. [PubMed: 15062780] (f) Burdette SC, Lippard SJ. Proc. Natl. Acad. Sci. U.S.A 2003;100:3605-3610. [PubMed: 12655069]

17. (a) Canzoniero LMT, Sensi SL, Choi DW. Neurobiol. Dis 1997;4:275-279. [PubMed: 9361304] (b) Kim TW, Park J, Hong J-I. J. Chem. Soc., Perkin Trans. 2 2002:923-927. (c) Gee KR, Zhou Z-L, Qian W-J, Kennedy R. J. Am. Chem. Soc 2002;124:776-778. [PubMed: 11817952] (d) Sensi SL, Ton-That D, Weiss JH, Rothe A, Gee KR. Cell Calcium 2003;34:281-284. [PubMed: 12887975] (e) Lim NC, Yao L, Freake HC, Brückner C. Bioorg. Med. Chem. Lett 2003;13:2251-2254. [PubMed: 12824012] (f) Koike T, Watanabe T, Aoki S, Kimura E, Shiro M. J. Am. Chem. Soc 1996;118:1269612703. (g) Kimura E, Ikeda T, Aoki S, Shionoya M. J. Inorg. Biol. Chem 1998;3:259-267. (h) Aoki S, Kaido S, Fujioka H, Kimura E. Inorg. Chem 2003;42:1023-1030. [PubMed: 12588134] (i) Hirano T, Kikuchi K, Urano Y, Higuchi T, Nagano T. Angew. Chem., Int. Ed 2000;39:1052-1054. (j) Hirano T, Kikuchi K, Urano Y, Higuchi T, Nagano T. J. Am. Chem. Soc 2000;122:12399-12400. (k) Hirano T, Kikuchi K, Urano Y, Nagano T. J. Am. Chem. Soc 2002;124:6555-6562. [PubMed: 12047174] (1) Czarnik A. Acc. Chem. Res 1994;27:302-308. (m) Wu Y, Peng X, Guo B, Fan J, Zhang Z, Wang J, Cui A, Gao Y. Org. Biomol. Chem 2005;5:1387-1392. [PubMed: 15827633]

18. (a) Maruyama S, Kikuchi K, Hirano T, Urano Y, Nagano T. J. Am. Chem. Soc 2002;124:1065010651. [PubMed: 12207508] (b) Henary MM, Wu Y, Fahrni CJ. Chem. Eur. J 2004;10:3015-3025. (c) Taki M, Wolford JL, O'Halloran TV. J. Am. Chem. Soc 2004;126:712-713. [PubMed: 14733534] (d) Lim NC, Brückner C. Chem. Commun 2004:1094-1095. (e) Chang CJ, Jaworski J, Nolan EM, Sheng M, Lippard SJ. Proc. Natl. Acad. Sci. U.S.A 2004;101:1129-1134. [PubMed: 14734801] (f) Woodroofe CC, Lippard SJ. J. Am. Chem. Soc 2003;125:11458-11459. [PubMed: 13129323] (g) Woodroofe CC, Won AC, Lippard SJ. Inorg. Chem 2005;44:3112-3120. [PubMed: 15847416] (h) Gee KR, Zhou Z-L, Ton-That D, Sensi SL, Weiss JH. Cell Calcium 2002;31:245-251. [PubMed: 12098227]

19. (a) Elbaum D, Nair SK, Patchan MW, Thompson RB, Christianson DW. J. Am. Chem. Soc 1996;118:8381-8387. (b) Thompson RB, Maliwal BP. Anal. Chem 1998;70:1749-1754. (c) Thompson RB, Whetsell WO, Maliwal BP, Fierke CA, Frederickson CJ. J. Neurosci. Methods 
2000;96:35-45. [PubMed: 10704669] (d) Fierke CA, Thompson RB. BioMetals 2001;14:205-222. [PubMed: 11831457] (e) Thompson RB, Cramer ML, Bozym R, Fierke CA. J. Biomed. Opt 2002;7:555-560. [PubMed: 12421121]

20. (a) Stewart JD, Roberts VA, Crowder MW, Getzoff ED, Benkovic SJ. J. Am. Chem. Soc 1994;116:415-416. (b) Godwin HA, Berg JM. J. Am. Chem. Soc 1996;118:6514-6515. (c) Walkup GK, Imperiali B. J. Am. Chem. Soc 1996;118:3053-3054. (d) Walkup GK, Imperiali B. J. Am. Chem. Soc 1997;119:3443-3450. (e) Shults MD, Pearce DA, Imperiali B. J. Am. Chem. Soc 2003;125:10591-10597. [PubMed: 12940742]

21. (a) Frederickson CJ, Kasarskis EJ, Ringo D, Frederickson RE. J. Neurosci. Methods 1987;20:91103. [PubMed: 3600033] (b) Zalewski PD, Millard SH, Forbes IJ, Kapaniris O, Slavotinek A, Betts WH, Ward AD, Lincoln SF, Mahadevan I. J. Histochem. Cytochem 1994;42:877-884. [PubMed: 8014471] (c) Kimber MC, Mahadevan IB, Lincoln SF, Ward AD, Tiekink ERT. J. Org. Chem 2000;65:8204-8209. [PubMed: 11101374] (d) Nasir MS, Fahrni CJ, Suhy DA, Kolodsick KJ, Singer CP, O’Halloran TV. J. Biol. Inorg. Chem 1999;4:775-783. [PubMed: 10631609] (e) Fahrni CJ, O’Halloran TV. J. Am. Chem. Soc 1999;121:11448-11458. (f) Zalewski PD, Forbes IJ, Seamark RF, Borlinghaus R, Betts WH, Lincoln SF, Ward AD. Chem. Biol 1993;1:153-161. [PubMed: 9383385] (g) Zalewski PD, Forbes IJ, Betts WH. Biochem. J 1993;296:403-408. [PubMed: 8257431] (h) Coyle P, Zalewski PD, Philcox JC, Forbes IJ, Ward AD, Lincoln SF, Mahadevan I, Rofe AM. Biochem. J 1994;303:781-786. [PubMed: 7980447]

22. (a) Burdette SC, Walkup GK, Spingler B, Tsien RY, Lippard SJ. J. Am. Chem. Soc 2001;123:78317841. [PubMed: 11493056] (b) Burdette SC, Frederickson CJ, Bu W, Lippard SJ. J. Am. Chem. Soc 2003;125:1778-1787. [PubMed: 12580603] (c) Nolan EM, Burdette SC, Harvey JH, Hilderbrand SA, Lippard SJ. Inorg. Chem 2004;43:2624-2635. [PubMed: 15074981] (d) Chang CJ, Nolan EM, Jaworski J, Burdette SC, Sheng M, Lippard SJ. Chem. Biol 2004;11:203-210. [PubMed: 15123282] (e) Chang CJ, Nolan EM, Jaworski J, Okamoto K-I, Hayashi Y, Sheng M, Lippard SJ. Inorg. Chem 2004;43:6774-6779. [PubMed: 15476377] (f) Woodroofe CC, Masalha R, Barnes KR, Frederickson CJ, Lippard SJ. Chem. Biol 2004;11:1659-1666. [PubMed: 15610850]

23. Anderegg G, Hubmann E, Podder NG, Wenk F. HelV. Chim. Acta 1977;60:123-140.

24. Nolan EM, Lippard SJ. Inorg. Chem 2004;43:8310-8317. [PubMed: 15606177]

25. Komatsu K, Kikuchi K, Kojima H, Urano Y, Nagano T. J. Am. Chem. Soc 2005;127:10197-10204. [PubMed: 16028930]

26. Brannon JH, Madge D. J. Phys. Chem 1978;82:705-709.

27. (a) Pearce DA, Jotterand N, Carrico IS, Imperiali B. J. Am. Chem. Soc 2001;123:5160-5161. [PubMed: 11457372] (b) Xue G, Bradshaw JS, Dalley NK, Savage PB, Izatt RM, Prodi L, Montalti M, Zaccheroni N. Tetrahedron 2002;58:4809-4815. (c) Mikata Y, Wakamatsu M, Yano S. Dalton Trans 2005:545-550. [PubMed: 15672199]

28. ChangCJNolanEMLippardSJUnpublished results

29. Sparano BA, Shahi SP, Koide K. Org. Lett 2004;6:1947-1949. [PubMed: 15176790]

30. (a) de Silva AP, Gunaratne HQN, Gunnlaugsson T, Huxley AJM, McCoy CP, Rademacher JT, Rice TE. Chem. ReV. 1997;97:1515-1566. [PubMed: 11851458] (b) de Silva AP, Fox DB, Huxley AJM, Moody TS. Coord. Chem. ReV. 2000;205:41-57.

31. Sjöback R, Nygren J, Kubista M. Spectrochim. Acta, Part A 1995;51:L7-L21.

32. Leonhardt H, Gordon L, Livingston R. J. Phys. Chem 1971;75:245-249.

33. (a) Jackson AP, Timmerman MP, Bagshaw CR, Ashley CC. FEBS Lett 1987;216:35-39. [PubMed: 3108033] (b) Kao JP, Tsien RY. Biophys. J 1988;53:635-639. [PubMed: 3382715] (c) Quast U, Labhardt AM, Doyle VM. Biochem. Biophys. Res. Commun 1984;123:604-611. [PubMed: 6487303]

34. Doose CA, Ranke J, Stock F, Bottin-Weber U, Jastorff B. Green Chem 2004;6:259-266.

35. Dineley KE, Malaiyandi LM, Reynolds IJ. Mol. Pharmacol 2002;62:618-627. [PubMed: 12181438]

36. (a) So PTC, Dong CY, Masters BR, Berland KM. Annu. ReV. Biomed. Eng. 2000;2:399-429.

[PubMed: 11701518] (b) Mainen ZF, Maletic-Savatic M, Shi SH, Hayashi Y, Malinow R, Svoboda K. Methods 1999;18:231-239. [PubMed: 10356355] (c) Williams RM, Zipfel WR, Webb WW. Curr. Opin. Chem. Biol 2001;5:603-608. [PubMed: 11578936] 


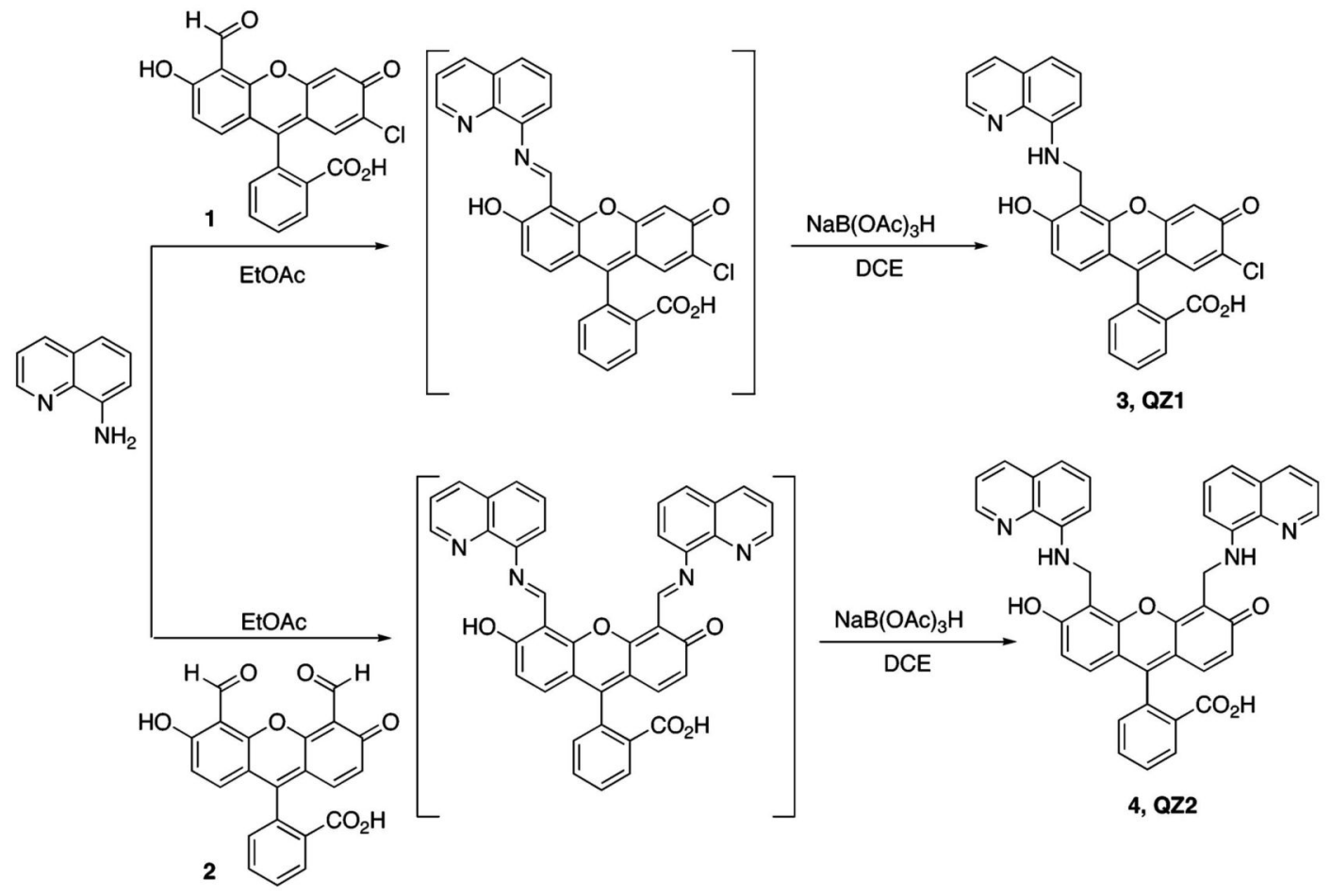

Scheme 1. 

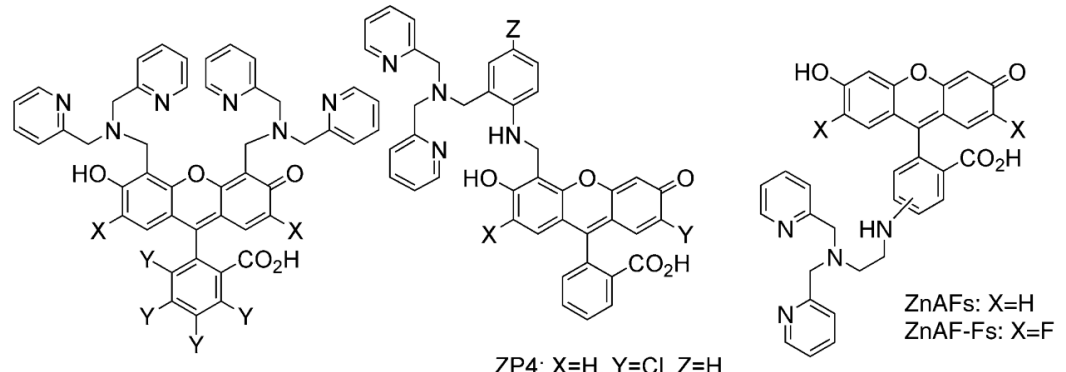

$\begin{array}{ll}\text { ZP1: } X=C l, Y=H & Z P F 1: X=C l, Y=F \\ \text { ZP2: } X=H, Y=H & Z P C l 1: X=C l, Y=C l \\ \text { ZP3: } X=F, Y=H & \text { ZPBr1: } X=C l, Y=B r \\ & \text { ZPF3: } X=F, Y=F\end{array}$

ZP4: $X=\mathrm{H}, Y=\mathrm{Cl}, \mathrm{Z=H}$ $Z P 5: X=H, Y=C l, Z=F$

$\mathrm{ZP} 6: \mathrm{X}=\mathrm{H}, \mathrm{Y}=\mathrm{Cl}, \mathrm{Z}=\mathrm{Cl}$ ZP7: $X=\mathrm{H} . Y=\mathrm{Cl}, Z=\mathrm{OMe}$ ZP8: $X=F, Y=F, Z=H$

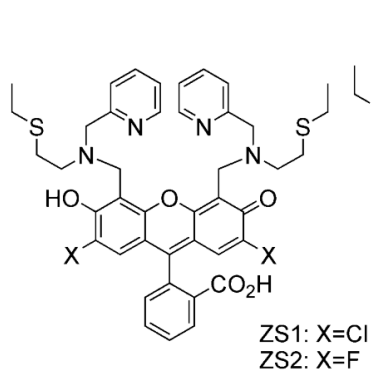<smiles></smiles><smiles></smiles><smiles>CCSCCN(CC)Cc1ccccc1NCc1c(O)ccc2c(-c3ccccc3C(=O)O)c3cc(Cl)c(=O)cc-3oc12</smiles><smiles>[R]Oc1cc(NS(=O)(=O)c2ccc(C)cc2)c2nc(P)ccc2c1</smiles>

TSQ: R'=H, R"=Me

Zinquin A: $\mathrm{R}^{\prime}=\mathrm{Me}, \mathrm{R}^{\prime \prime}=\mathrm{CH}_{2} \mathrm{CO}_{2} \mathrm{H}$ Zinquin $\mathrm{E}: \mathrm{R}^{\prime}=\mathrm{Me}, \mathrm{R}^{\prime \prime}=\mathrm{CH}_{2} \mathrm{CO}_{2} \mathrm{Et}$

Figure 1.

Selected fluorescent sensors for Zn(II). The ZP, ZS, and ZnAF dyes are all fluorescein-based and give fluorescence enhancement upon $\mathrm{Zn}$ (II) coordination. The quinoline sulfonamides, which include TSQ and Zinquin, are the most commonly used biological Zn(II) stains and also give fluorescence turn-on following $\mathrm{Zn}(\mathrm{II})$ binding. 

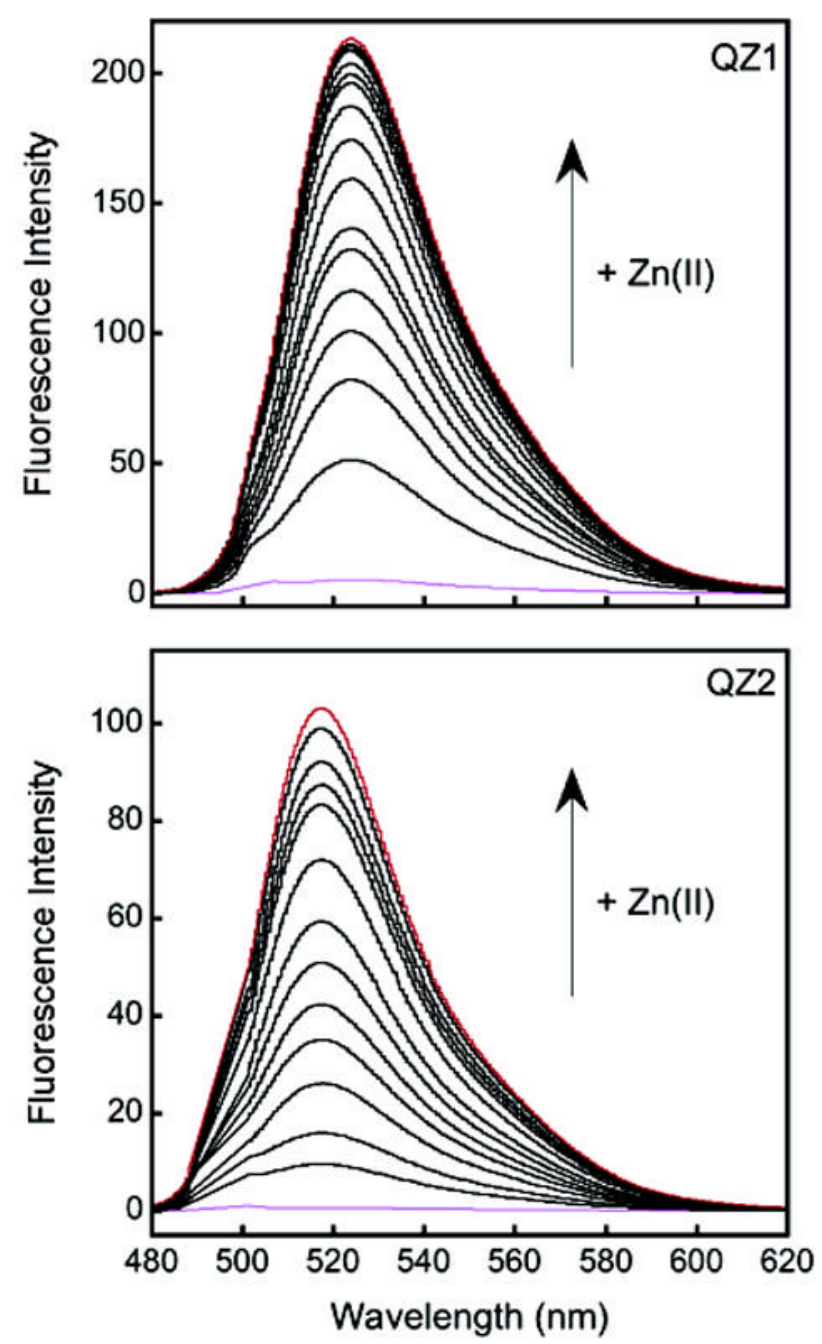

Figure 2.

Fluorescence response of QZ1 and QZ2 to Zn(II) at pH 7 (50 mM PIPES, $100 \mathrm{mM} \mathrm{KCl).} \mathrm{Top:}$ Emission of QZ1 before and after $\mathrm{Zn}$ (II) addition. Aliquots of 10 and $100 \mathrm{mM} \mathrm{ZnCl}_{2}$ in water were added to yield $\mathrm{Zn}$ (II) concentrations of $0,10,20,30,40,50,60,93,127,193,260,327$, $392,460,526,593,760$, and $927 \mu \mathrm{M}$. [QZ1] $=1 \mu \mathrm{M} ; \lambda_{\mathrm{ex}}=500 \mathrm{~nm}$. Bottom: Emission of QZ2 before and after $\mathrm{Zn}$ (II) addition. Aliquots of 100 and $500 \mathrm{mM} \mathrm{ZnCl}_{2}$ were added to yield $\mathrm{Zn}$ (II) concentrations of $0,0.05,0.1 .0 .2,0.35,0.5,0.7,1.0,1.5,2.0,2.75,3.75,4.75$, and 6.75 mM. $[Q Z 2]=1 \mu \mathrm{M} ; \lambda_{\mathrm{ex}}=490 \mathrm{~nm}$. 


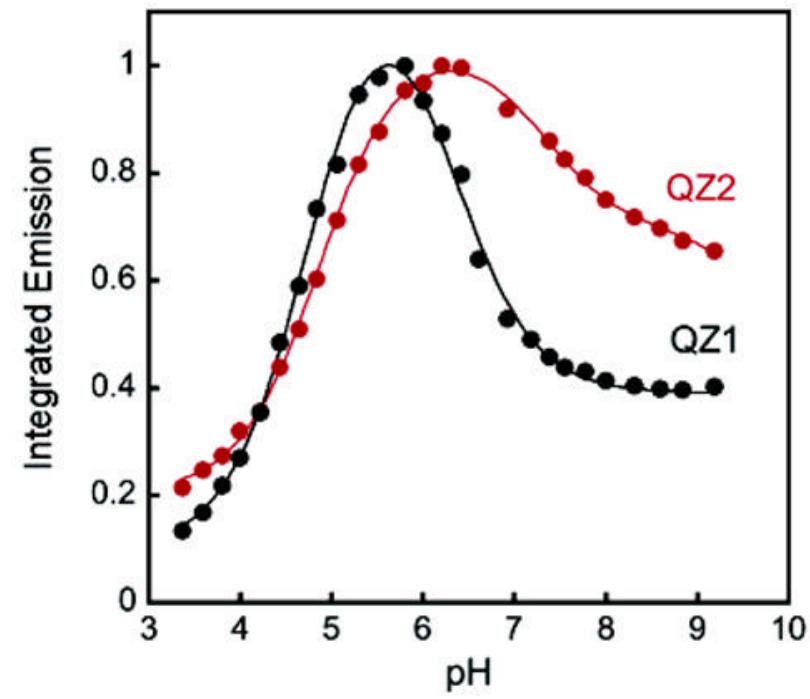

Figure 3.

Fluorescence dependence on $\mathrm{pH}$ for QZ1 (black) and QZ2 (red). Solutions of $1 \mu \mathrm{M}$ QZ were prepared in $10 \mathrm{mM} \mathrm{KOH}, 100 \mathrm{mM} \mathrm{KCl}, \mathrm{pH} \sim 12$, and the emission spectra recorded. The $\mathrm{pH}$ was decreased in increments of $\sim 0.25$ by addition of $6,2,1,0.5$, and $0.1 \mathrm{~N} \mathrm{HCl}$, and the emission spectra were recorded at each point. The emission was integrated, normalized, and plotted against $\mathrm{pH}$. Excitation was provided at $495 \mathrm{~nm}$. Points above $\mathrm{pH} \sim 10$ are omitted from the plot since no significant emission changes occurred. 


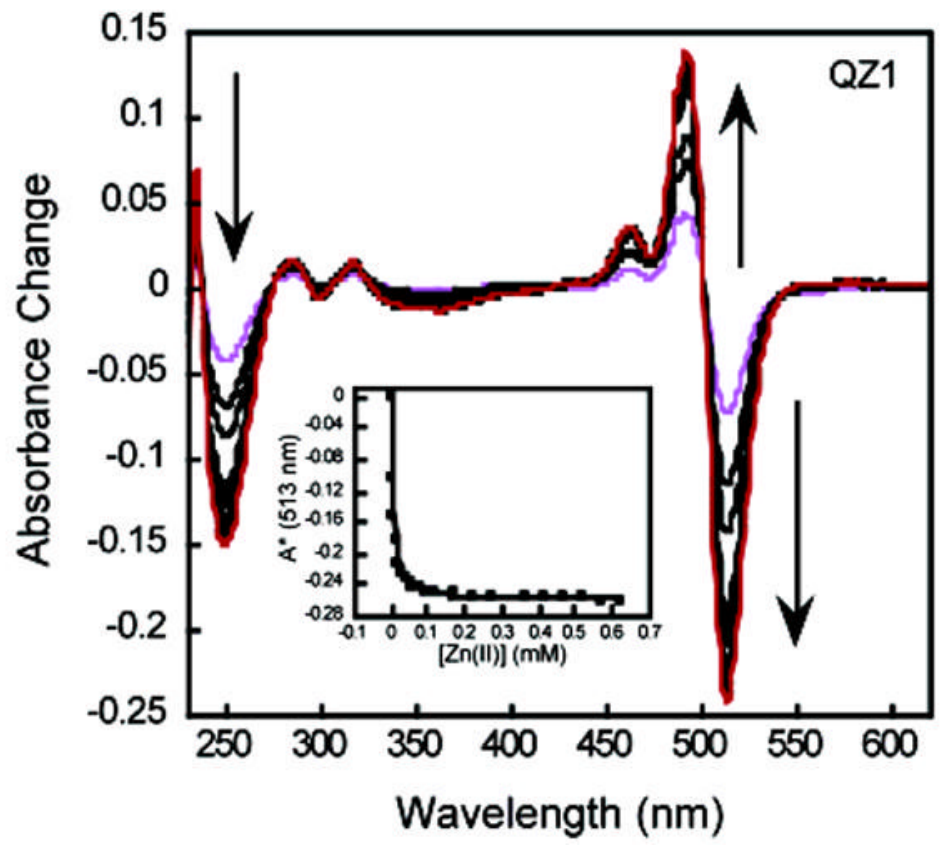

Figure 4.

Optical absorption difference spectra for the addition of $\mathrm{Zn}$ (II) to QZ1 at pH 7 (50 mM PIPES, $100 \mathrm{mM} \mathrm{KCl}$ ). Decreases in absorption are observed at 513 and $250 \mathrm{~nm}$, whereas absorption increases occur at 492, 462, 317, and $283 \mathrm{~nm}$. Inset: The absorption change at $513 \mathrm{~nm}$ plotted against the concentration of $\mathrm{Zn}$ (II) in solution. The absorption due to the free dye was subtracted from all data. $[\mathrm{QZ1}]=5 \mu \mathrm{M}$. 

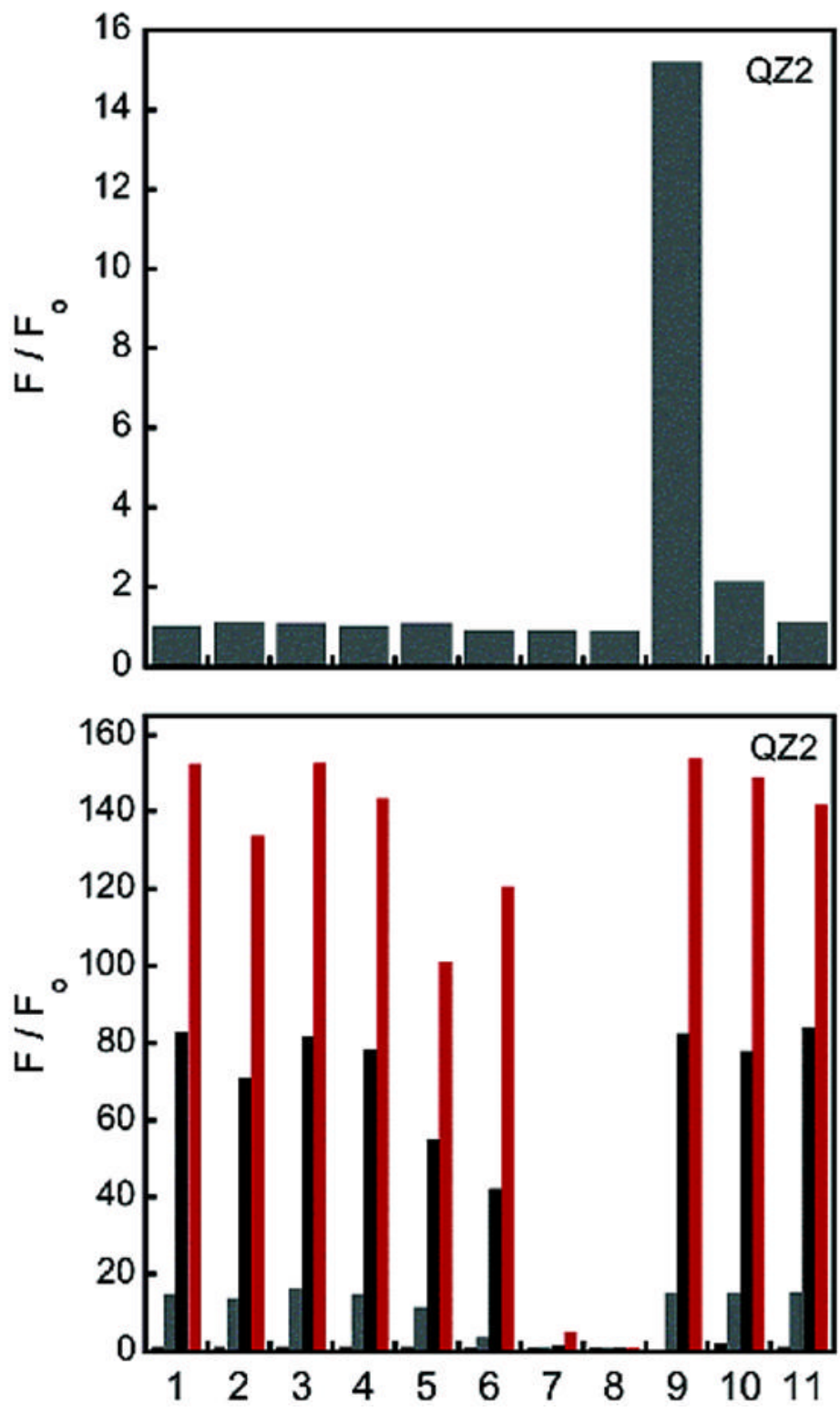

Figure 5.

Selectivity of QZ2 for Zn(II). Top: Fluorescence response of QZ2 following addition of 50 equiv of the metal ion of interest: $\mathbf{1}, \mathrm{Na}(\mathrm{I}) ; \mathbf{2}, \mathrm{Ca}(\mathrm{II}) ; \mathbf{3}, \mathrm{Mg}(\mathrm{II}) ; \mathbf{4}, \mathrm{Mn}(\mathrm{II}) ; \mathbf{5}, \mathrm{Fe}(\mathrm{II}) ; \mathbf{6}, \mathrm{Co}(\mathrm{II})$; 7, Ni(II); 8, Cu(II); 9, Zn(II); 10, Cd(II); 11, Hg(II). Bottom: Selectivity of QZ2 for Zn(II) over the metal ions of interest. Black bars: QZ2 + 50 equiv cation, as shown in the top panel. Light gray bars: addition of 50 equiv of $\mathrm{Zn}(\mathrm{II})$ to the solution containing QZ2 and the cation of interest. Dark gray bars: introduction of an additional 450 equiv of $\mathrm{Zn}(\mathrm{II})$ to the solution containing QZ2 and the cation of interest. Red bars: introduction of an additional 2000 equiv of $\mathrm{Zn}(\mathrm{II})$. Samples were excited at $495 \mathrm{~nm}$, and the emission spectra were integrated from 510 to $650 \mathrm{~nm}$. All data $(F)$ are normalized with respect to the emission of the free dye $\left(F_{\mathrm{o}}\right)$. [QZ2] $=1 \mu \mathrm{M} . \mathrm{QZ1}$ data are given as Supporting Information (Figure S4). 


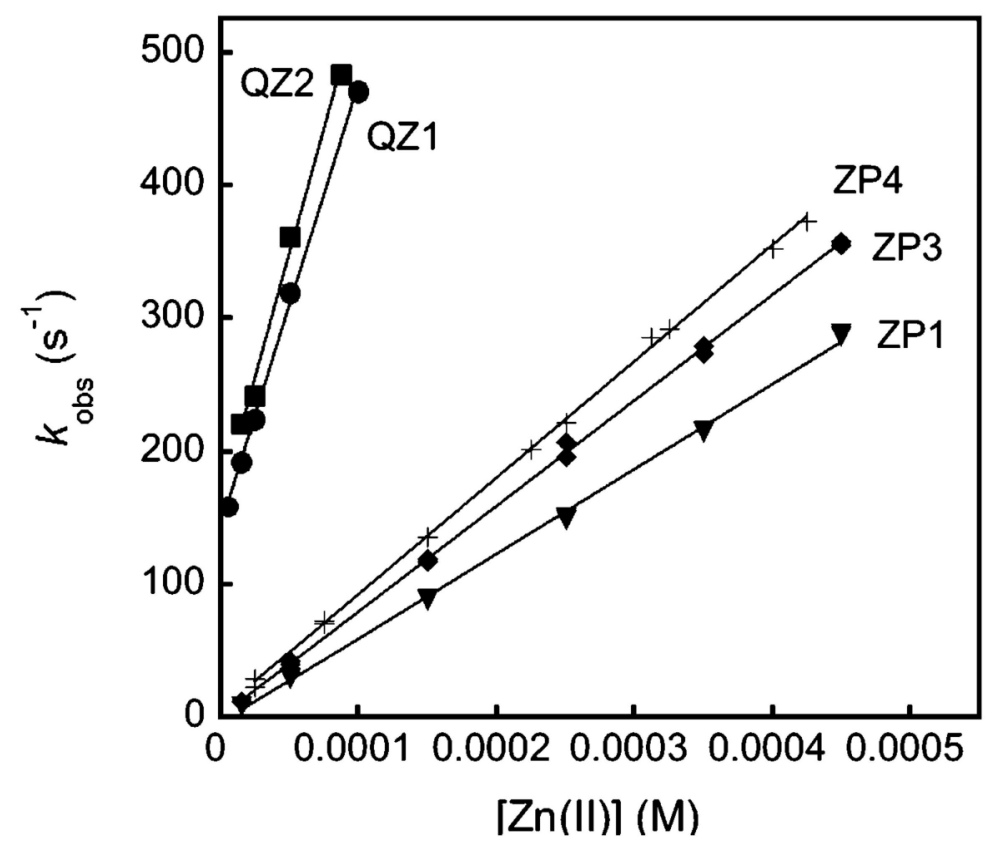

Figure 6.

Results from stopped-flow fluorescence studies of $\mathrm{Zn}(\mathrm{II})$ binding to various $\mathrm{Zn}$ (II) sensors. Plots of $k_{\mathrm{obs}}$ vs concentration of Zn(II) for QZ1 (b), QZ2 (9), ZP1 (2), ZP3 ([), and ZP4 (+). All data were collected at $4.3 \pm 0.1{ }^{\circ} \mathrm{C}$. See the Supporting Information for kinetic traces, monoexponential fits, individual plots, and experimental details. 


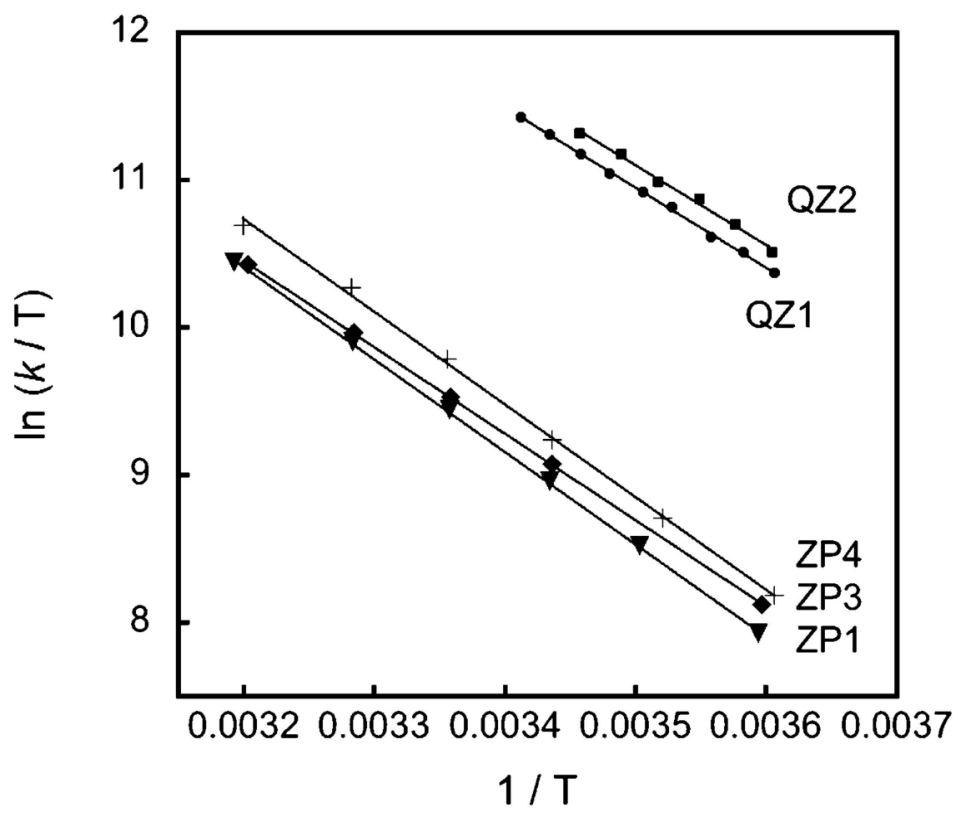

Figure 7.

Eyring plots for QZ1 $(\bullet)$, QZ2 (•), ZP1 ( $\mathbf{\Delta}), \mathrm{ZP} 3(\bullet)$, and ZP4 (+). The temperature was varied from $\sim 4$ to $\sim 16{ }^{\circ} \mathrm{C}(\mathrm{QZ})$ or from $\sim 4$ to $\sim 40{ }^{\circ} \mathrm{C}(\mathrm{ZP})$. Calculated values for $\Delta H^{*}$ and $\Delta S^{\ddagger}$ are given in Table 2 . 


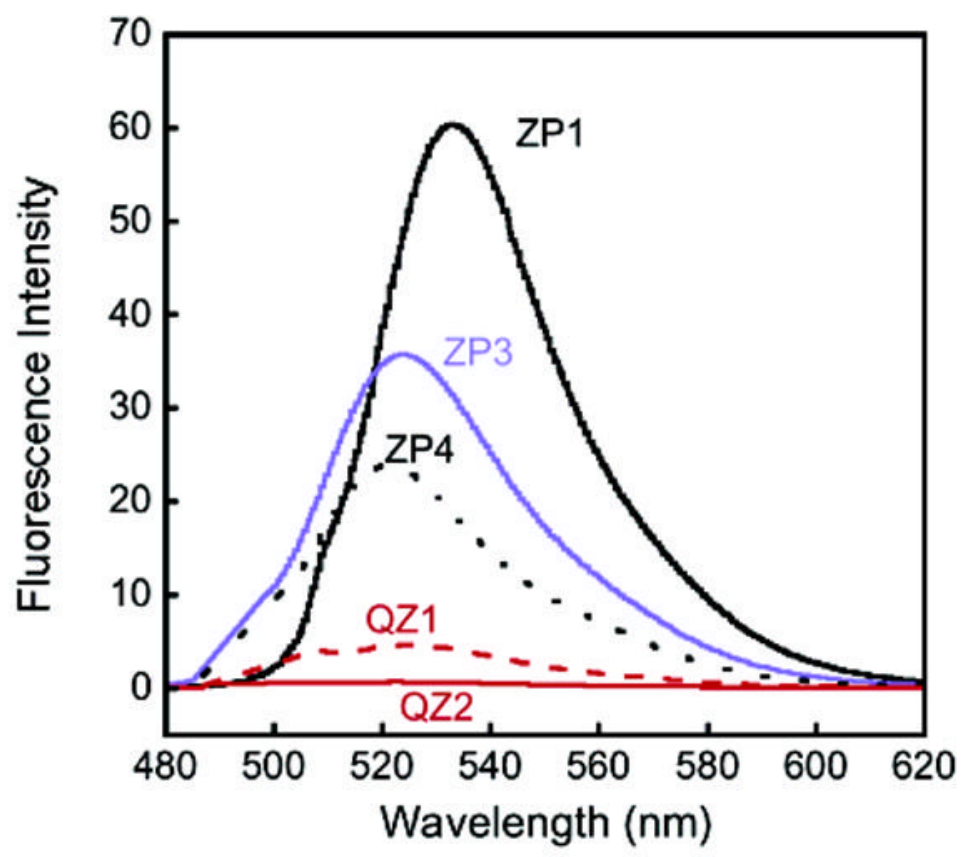

Figure 8.

Relative fluorescence emission of $1 \mu \mathrm{M}$ ZP1, ZP3, ZP4, QZ1, and QZ2. Solutions were prepared at pH 7 with $50 \mathrm{mM}$ PIPES, $100 \mathrm{mM} \mathrm{KCl,} \mathrm{pH} \mathrm{7,} \mathrm{with} \mathrm{excess} \mathrm{EDTA.}$ 

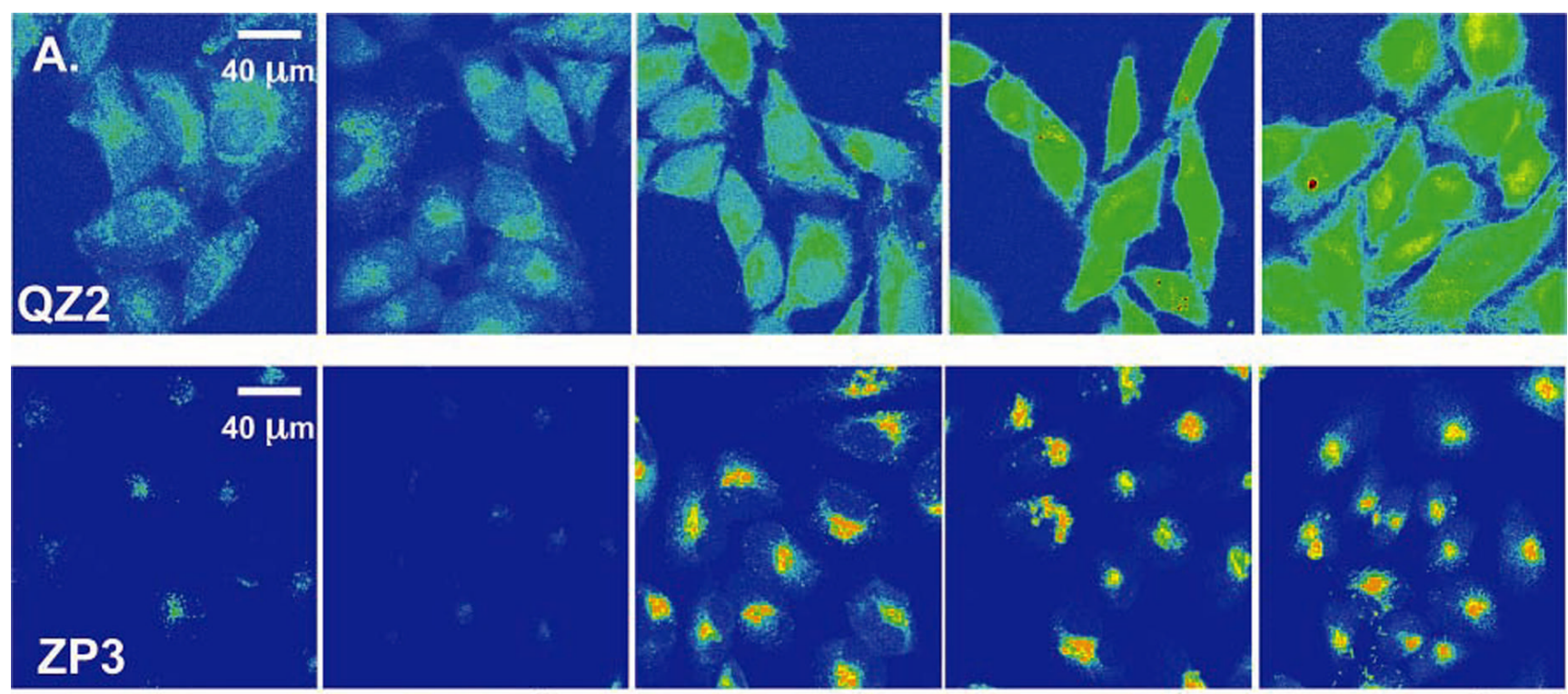

$10 \mu \mathrm{M}$ dye

$+10 \mu \mathrm{M} \mathrm{Zn^{2+ }}$

$+50 \mu \mathrm{M} \mathrm{Zn}^{2+}$

$+100 \mu \mathrm{M} \mathrm{Zn}^{2+}$

$+200 \mu \mathrm{M} \mathrm{Zn}^{2+}$

B.
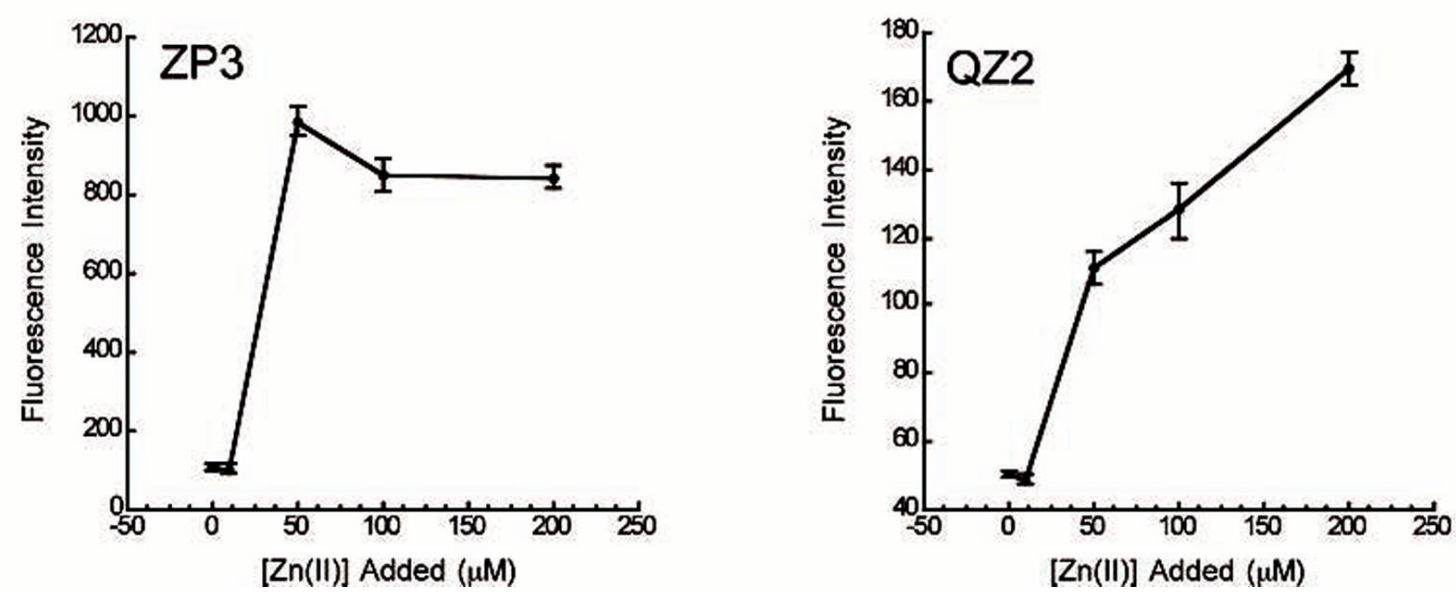

Figure 9.

(A) Confocal imaging of fixed HeLa cells treated with QZ2 or ZP3. Top panels: HeLa cells treated with $10 \mu \mathrm{M}$ QZ2 $\left(4 \mathrm{~h}, 37^{\circ} \mathrm{C}\right)$ and varying concentrations of $\mathrm{Zn}(\mathrm{II})$. Bottom panels: HeLa cells treated with $10 \mu \mathrm{M}$ ZP3 $\left(30 \mathrm{~min}, 37^{\circ} \mathrm{C}\right.$ ) and varying concentrations of $\mathrm{Zn}(\mathrm{II})$. The cells were washed once with DMEM containing no FCS before $\mathrm{Zn}$ (II) addition and were incubated with $\mathrm{Zn}(\mathrm{II})$ for $10 \mathrm{~min}$ at $37^{\circ} \mathrm{C}$ prior to fixing. A 10:2 $\mathrm{Zn}(\mathrm{II}) /$ pyrithione ratio was employed. (B) Quantification of the fluorescence response. Left plot: Quantification of ZP3 response. The fluorescence observed in the Golgi was monitored. Right plot: Quantification of QZ2 response. The error bars represent the standard error of the mean (sem) and $p<0.001$ for the increase observed for QZ2 (Mann-Whitney test). A minimum of 29 cells were quantified at each $\mathrm{Zn}(\mathrm{II})$ concentration. 

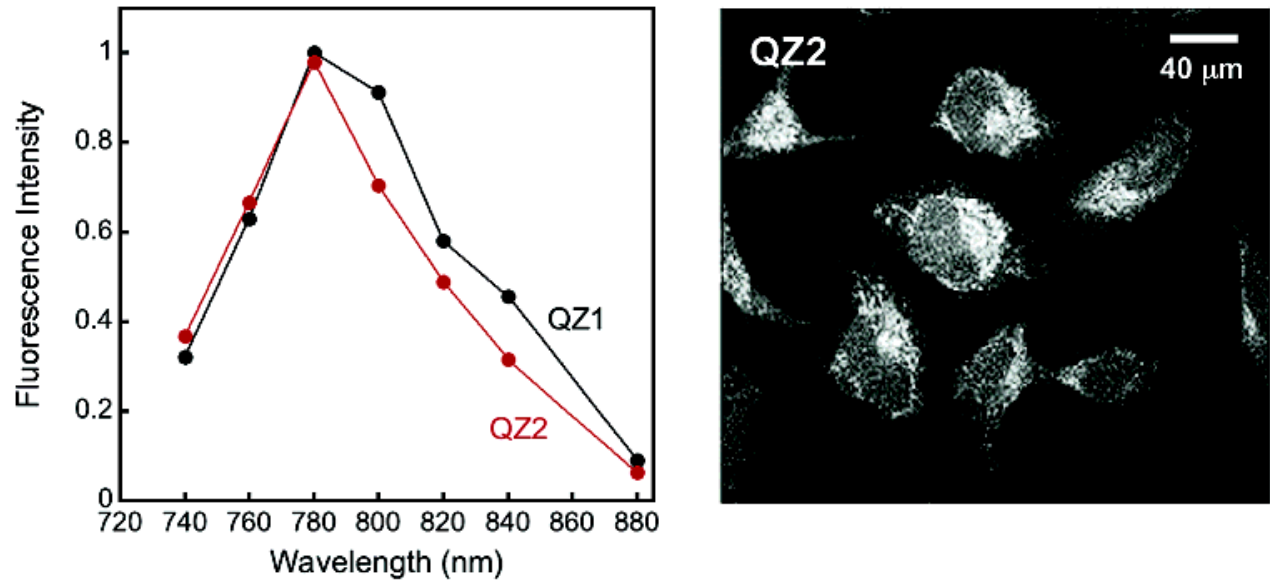

Figure 10.

Left: Two-photon excitation profiles for QZ1 (black circles) and QZ2 (red circles) in the presence of $100 \mu \mathrm{M} \mathrm{Zn(II).} \mathrm{The} \mathrm{solutions} \mathrm{were} \mathrm{prepared} \mathrm{in} 50 \mathrm{mM}$ PIPES, $100 \mathrm{mM} \mathrm{KCl}, \mathrm{pH}$ 7 , and $[\mathrm{QZ}]=10 \mu \mathrm{M}$. The emission was monitored from 0 to $570 \mathrm{~nm}$. Right: TPM imaging of live HeLa cells treated with $10 \mu \mathrm{M}$ QZ2 (4 h) and $100 \mu \mathrm{M} \mathrm{Zn(II)} \mathrm{(5} \mathrm{min,} \mathrm{10:2} \mathrm{Zn(II)/pyrithione,}$ $T=37^{\circ} \mathrm{C}$ ). 


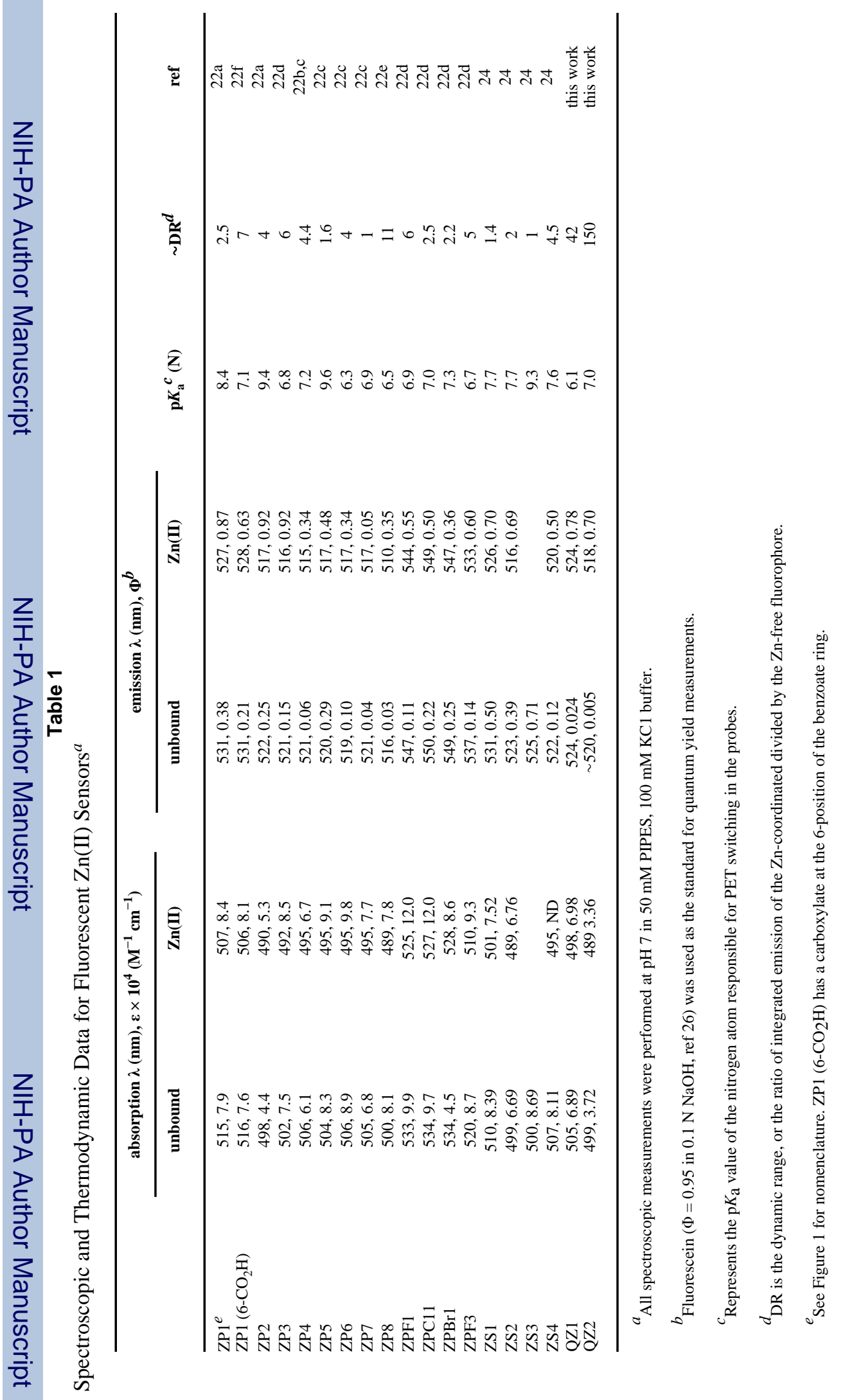




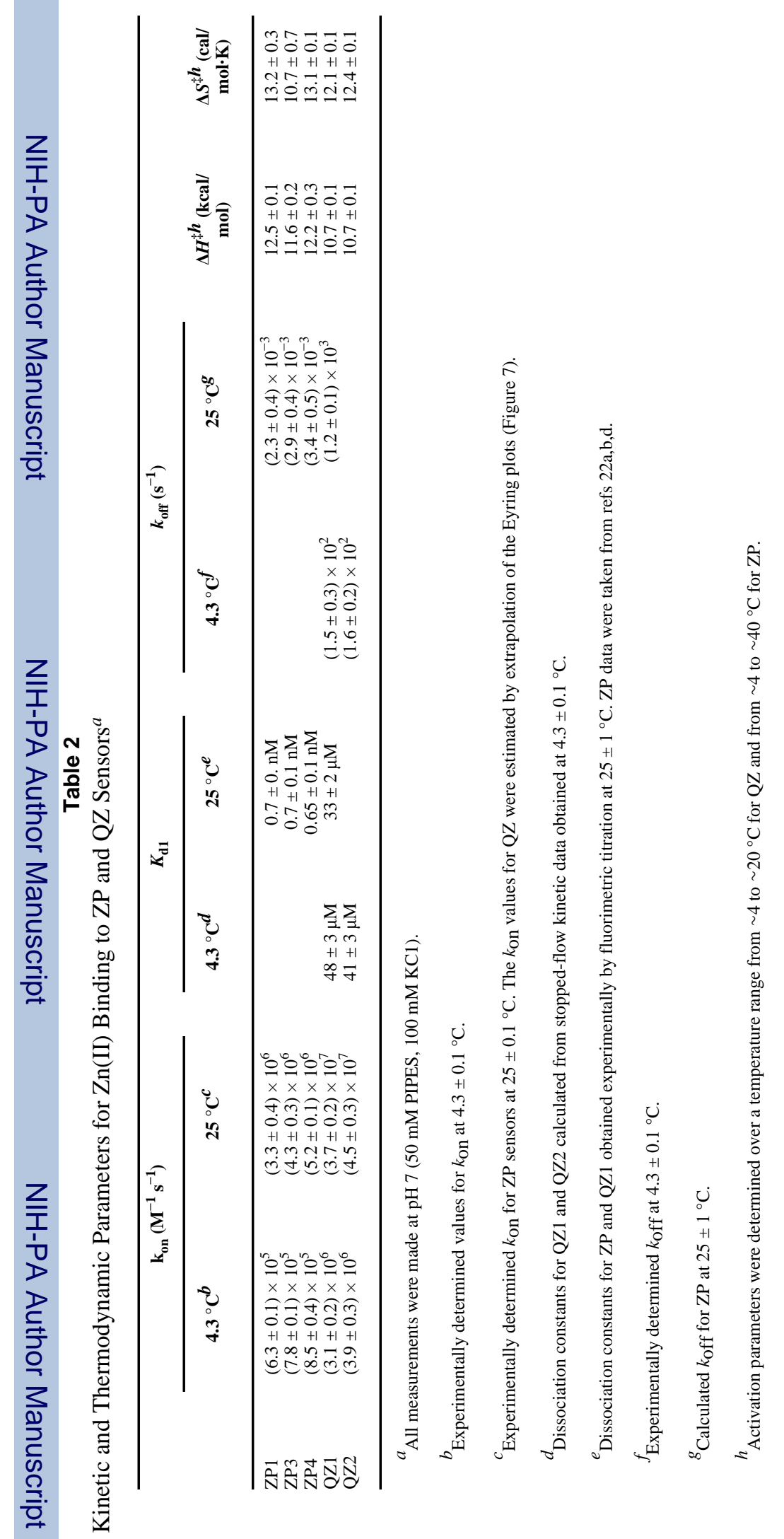

